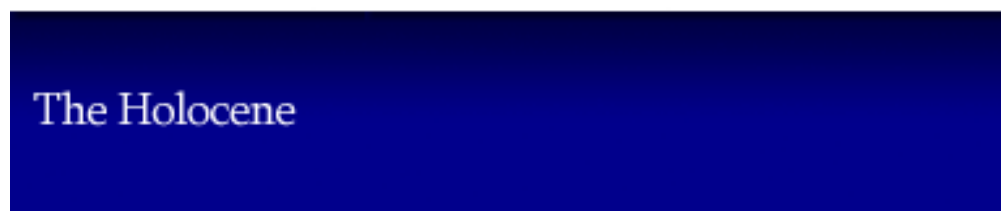

\title{
Early human impact on soils and hydro-sedimentary systems: multi-proxy geoarchaeological analyses from La Narse de la Sauvetat (France)
}

\begin{tabular}{|c|c|}
\hline Journal: & The Holocene \\
\hline Manuscript ID & HOL-19-0169.R2 \\
\hline Manuscript Type: & Paper \\
\hline $\begin{array}{r}\text { Date Submitted by the } \\
\text { Author: }\end{array}$ & $n / a$ \\
\hline Complete List of Authors: & $\begin{array}{l}\text { Mayoral, Alfredo; Clermont Auvergne University, GEOLAB UMR 6042; } \\
\text { Institut Catala d'Arqueologia Classica } \\
\text { Granai, Salome; GéoArchEon; UMR } 8591 \\
\text { Develle, Anne-Lise; UMR 5204 EDYTEM } \\
\text { Peiry, Jean-Luc; Clermont Auvergne University; UMR } 5204 \text { EDYTEM } \\
\text { Miras, Yannick; Histoire naturelle de I'Homme prehistorique, UMR } 7194 \\
\text { CNRS; Clermont Auvergne University, GEOLAB UMR } 6042 \\
\text { Couderc, Florian; UMR 5608 TRACES } \\
\text { Vernet, Gérard; GEOLAB UMR 6042-INRAP } \\
\text { Berger, Jean-François; UMR 5600, CNRS }\end{array}$ \\
\hline Keywords: & $\begin{array}{l}\text { Geoarchaeology, Palaeoenvironment, Socio-environmental interaction, } \\
\text { Anthropogenic impact, Holocene, Limagne }\end{array}$ \\
\hline Abstract: & $\begin{array}{l}\text { We analyzed the Late Holocene pedo-sedimentary archives of La Narse } \\
\text { de la Sauvetat, a hydromorphic depression in the southern Limagne plain } \\
\text { (central France), where chronologically accurate studies are scarce. The } \\
\text { multi-proxy geoarchaeological and palaeoenvironmental analysis of two } \\
\text { cores from different areas of the basin was carried out through } \\
\text { sedimentological, geochemical, micromorphological and malacological } \\
\text { investigations. Integration of these datasets supported by a robust } \\
\text { radiocarbon-based chronology allowed discussion of socio-environmental } \\
\text { interactions and anthropogenic impacts from Late Neolithic to Early } \\
\text { Middle Ages. Until the Middle Bronze Age, there was no clear evidence of } \\
\text { anthropogenic impact on soils and hydro-sedimentary dynamics of the } \\
\text { catchment, but two peaks of high alluvial activity probably related to the } \\
4.2 \text { and } 3.5 \text { kyr. BP climate events were first recorded in Limagne. } \\
\text { Significant anthropogenic impacts started in the Late Bronze Age with } \\
\text { increased erosion of the surrounding volcanic slopes. However, a major } \\
\text { threshold was reached c. } 2600 \text { cal BP with a sharp increase in the } \\
\text { catchment erosion interpreted as resulting from strong anthropogenic } \\
\text { environmental changes related to agricultural activities and drainage. } \\
\text { This implies an anthropogenic forcing on soils and hydro-sedimentary } \\
\text { systems much earlier than was usually considered in Limagne. These } \\
\text { impacts then gradually increased during Late Iron Age and Roman } \\
\text { periods, but environmental effects were certainly contained by progress } \\
\text { in agricultural management. Late Antiquity environmental changes are } \\
\text { consistent with regional trend to drainage deterioration in lowlands, but }\end{array}$ \\
\hline
\end{tabular}


marked asynchrony in this landscape change suggests that societal factors implying differential land management were certainly predominant here.

\section{SCHOLARONE Manuscripts}




\section{Early human impact on soils and hydro-sedimentary systems: multi-proxy} geoarchaeological analyses from La Narse de la Sauvetat (France)

MAYORAL, Alfredo* (1); GRANAI, Salomé (2); DEVELLE, Anne-Lise (3); PEIRY, Jean-Luc (4); MIRAS, Yannick (5); COUDERC, Florian (6); VERNET, Gérard (7); BERGER, Jean-François (8)

1. Université Clermont Auvergne, CNRS, GEOLAB, F-63000 Clermont-Ferrand, France \& Catalan Institute of Classical Archaeology, PI. Rovellat s/n, 43003 Tarragona, Spain.

2. GéoArchÉon, 30 Rue de la Victoire, 55210 Vigneulles-lès-Hattonchâtel \& CNRS, Université Paris 1, UPEC. UMR8591, Laboratoire de Géographie Physique : Environnements Quaternaires et Actuels, 1 place Aristide Briand, 92195 Meudon, France

\section{UMR 5204 EDYTEM, Université Savoie Mont Blanc, CNRS, 7337 Le Bourget du Lac, France}

4. Université Clermont Auvergne, F-63000 Clermont-Ferrand \& CNRS, EDYTEM, F-73000 Chambéry, France

5. CNRS, UMR7194, Histoire Naturelle de l'Homme Préhistorique, Département de Préhistoire, Muséum National d'Histoire Naturelle, Institut de Paléontologie Humaine, Paris, France \& Université Clermont Auvergne, CNRS, GEOLAB, F-63000 Clermont-Ferrand, France

6. UMR 5608 TRACES, Université Toulouse 2 Jean Jaurès, CNRS, Toulouse, France

7. Université Clermont Auvergne, CNRS, INRAP, GEOLAB, F-63000 Clermont-Ferrand, France

8. CNRS, UMR 5600, EVS-IRG \& Université Lyon 2, Lyon, France

*corresponding author : alfredo.mayoral@uca.fr

Abstract: We analyzed the Late Holocene pedo-sedimentary archives of La Narse de la Sauvetat, a hydromorphic depression in the southern Limagne plain (central France), where chronologically 
accurate studies are scarce. The multi-proxy geoarchaeological and palaeoenvironmental analysis of two cores from different areas of the basin was carried out through sedimentological, geochemical, micromorphological and malacological investigations. Integration of these datasets supported by a robust radiocarbon-based chronology allowed discussion of socio-environmental interactions and anthropogenic impacts from Late Neolithic to Early Middle Ages. Until the Middle Bronze Age, there was no clear evidence of anthropogenic impact on soils and hydro-sedimentary dynamics of the catchment, but two peaks of high alluvial activity probably related to the 4.2 and $3.5 \mathrm{kyr}$. BP climate events were first recorded in Limagne. Significant anthropogenic impacts started in the Late Bronze Age with increased erosion of the surrounding volcanic slopes. However, a major threshold was reached c. 2600 cal BP with a sharp increase in the catchment erosion interpreted as resulting from strong anthropogenic environmental changes related to agricultural activities and drainage. This implies an anthropogenic forcing on soils and hydro-sedimentary systems much earlier than was usually considered in Limagne. These impacts then gradually increased during Late Iron Age and Roman periods, but environmental effects were certainly contained by progress in agricultural management. Late Antiquity environmental changes are consistent with regional trend to drainage deterioration in lowlands, but marked asynchrony in this landscape change suggests that societal factors implying differential land management were certainly predominant here.

Keywords: Geoarchaeology, Palaeoenvironment, Socio-environmental interactions, Anthropogenic impact, Holocene, Limagne

\section{1-Introduction}

Middle Holocene is now generally considered as the beginning of anthropogenic impact on natural systems, which becomes gradually stronger and more generalized during the Late Holocene (Crutzen \& Stoermer, 2000; Ellis et al., 2017; Nichols \& Gogineni, 2018; Ruddiman et al., 2015; Ruddiman, 2018). From a geomorphological perspective, the crucial step is the generalized and intensive anthropogenic modification of geomorphic processes, such as soil erosion, hydro-sedimentary 
system forcing and pronounced development of anthropogenic landforms (Brown et al., 2016; Goudie and Viles, 2016; Walsh et al., 2019).

In north-western Europe, this threshold appeared to occur in the third millennium BP (Dotterweich, 2013; Ellis et al., 2013; Notebaert, Berger, \& Brochier, 2014; Ruddiman, 2003). While the forcing of geomorphological processes in Roman times or at the end of the Iron Age is now accepted, some authors argue that it could have occurred centuries earlier (e.g. Dreibrodt et al., 2010; Gebhardt, Occhietti, \& Fechner, 2014; Houben et al., 2012; Lang, 2003; Notebaert \& Berger, 2014), in connection with the development of a centralization and complexification phenomenon sometimes qualified as "proto-urban" in central-western Europe (Fernández-Götz, 2018).

However, there are still some key open questions as the rates and thresholds in the broadly increasing pace of anthropogenic impacts, or the relative contribution and interactions between anthropogenic and climatic drivers. Spatial and temporal variability of anthropogenic impacts and associated geomorphological responses, and a general scarcity of high-resolution, continuous and robust datasets are amongst the main difficulties (Brown et al., 2013; 2016). Indeed, some areas such as the Rhône valley in SE France are extensively studied (e.g. Berger, Shennan, \& Woodbridge, 2019), whereas other neighboring areas suffer from a dearth of analysis, poor data resolution or other issues making a regional synthesis and discussion problematic.

Our work aimed to contribute to this scientific challenge providing new data in the Limagne plain (central France) where even recent Holocene palaeoenvironmental and geoarchaeological research often lacked chronological accuracy. This lack of chronological accuracy has hindered proper discussion of socio-environmental interactions during critical protohistoric periods, despite abundant studies conducted since the 2000s (Ballut, 2001; Macaire et al., 2010; Trément, 2007a; Trément, 2011; Vernet, 2013). The main objective of this study was therefore to bring out new multi-proxy palaeoenvironmental and geoarchaeological data at high chronological resolution in Limagne, and 
subsequently use them to discuss interactions of human activities with natural landscapes, especially with soils and hydro-sedimentary system of the catchment, as well as local vegetation and hydrology.

We focused on a hydromorphic depression called La Narse de la Sauvetat located in the marly lowlands of the southern Limagne, surprisingly neglected by palaeoenvironmentalists until recently. Since 2014, first preliminary works detected particularly high potential for palaeoenvironmental studies, encouraging further research (Mayoral et al., 2018). The basin is a flat depression with a W-E elongated shape ( $2 \mathrm{~km} \times 800 \mathrm{~m}$ approx.) and a surface of c. $1,2 \mathrm{~km}^{2}$, dug in the Cenozoic calcareous rocks of southern Limagne lowlands (Fig. 1).

In this area, the so-called Limagne des Buttes, incision of the drainage network after Miocene and Pliocene volcanism (Nehlig et al., 2003) gradually created inverted volcanic reliefs from the basaltic lava flows and domes (500 to 800 masl.), which now dominate the eroded sedimentary lowlands (300-400 masl.). The slopes of these volcanic reliefs are covered by sedimentary or volcanosedimentary colluvium, sometimes with decametric thickness, and are affected by mass movements and landslides (Greffier et al., 1980). Lowlands around the basin have a gentle topography, with some structural reliefs in marls and limestones. La Narse de la Sauvetat catchment (c. $\left.16 \mathrm{~km}^{2}\right)$ is therefore limited by volcanic plateaus and domes at the East and West (Puy de Corent, Puy de SaintSandoux and Puy de Peyronère), a Pleistocene residual terrace of the Allier river to the North, and small structural mounds to the South (Fig. 1B-C).

Water and sediment fluxes come mainly from westward colluvial slopes (Puy de Saint-Sandoux, Puy de Peyronère), concentrated in several small flat valleys and are finally directed to the bottom of the depression to the east (min. 368 masl.). The basin is naturally closed by a topographic threshold in its eastern border and is therefore disconnected from drainage network, causing development of dark hydromorphic soils with isohumic/vertic features which are nowadays artificially drained and cultivated (see Fig. 1). Climate in the area is oceanic to semi-continental with cold and relatively dry winters, and hot and stormy summers (Joly et al., 2010). Soils of the catchment include a variety of 
brown soils on volcanic and/or calcareous materials, colluvial soils and regosoils on marls, gleyic alluvial soils, and the aforementioned hydromorphic soils in the depressions (Bornand et al., 1968, see Fig. 1D).

First research works provided supplementary geomorphological data on the nature of the basin and its main phases of morpho-stratigraphic and pedo-sedimentary evolution (Mayoral et al., 2018). A $6 \mathrm{~m}$-thick alluvio-colluvial sedimentary infilling was investigated through hand auger cross-sections (Fig. 2). Alluvial sedimentary dynamics have shown that La Narse de la Sauvetat was a palaeovalley connected to local drainage from the Upper Pleistocene until the mid-Holocene period, when a massive landslide formed the topographic threshold blocking its eastern outlet (see Fig. 1). Sudden damming of the valley temporarily formed a lake, ultimately recaptured by headward erosion. The drainage network remained nevertheless disturbed and poorly hierarchized and consequently the area became an hydromorphic plain after c. 4850 cal BP, with palustrine and lacustrine phases until its drainage in 1768 AD (Daugas and Tixier, 1977; Mayoral et al., 2018).

The basin is also situated within the rich protohistoric archaeological context of the Limagne plain, with a particularly dense and well-known record from the Neolithic to the Roman period (Provost and Mennessier-jouannet, 1994; Vallat, 2002). However, at a local scale the neighboring hilltop site of the Puy de Corent, with multi-period occupations (Fig. 1C) crucial for territorial structuring from the Neolithic to the Iron Age, has been the focus of almost all the research and findings. As a consequence of this research bias, archaeological discoveries are rather scarce in the lowlands surrounding La Narse de la Sauvetat basin. In general the Neolithic is poorly known in the lowlands due to the lack of findings, however in the Puy de Corent developed settlements are known especially in the second part of the Middle Neolithic (Poux et al., 2018). Most phases of the Bronze Age are also poorly documented in the study area, however during the Middle Bronze Age a small occupation is noted (Pranly, Fig. 1C). By contrast, extended settlements develop at Corent during the Middle and the Late Bronze Age, and also during the Early Iron Age (Milcent et al., 2014; Poux et al., 
121 2018). During the latter period, a small site is also known in the lowlands (Les Orneufs, Fig. 1C). The

122 area is especially known for the Late Iron Age (La Tène) extensive oppidum of Corent (Poux, 2012;

123 Poux et al., 2018), however lowlands around La Narse de la Sauvetat again lack archaeological

124 remains for this period. The only phase with abundant archaeological remains in la Sauvetat plain is 125 the Roman era, as a secondary agglomeration develops at Corent. Several sites are documented 126 around La Narse basin, including farms, a sanctuary and an extensive villa, indicating an intense 127 exploitation of the area (Simon et al., 2017; Vallat, 2002).

128 With a view to fully use the set of palaeoenvironmental records of this sedimentary archive from the 129 second part of the Holocene, we present here a multi-proxy geoarchaeological and 130 palaeoenvironmental analysis of the upper infilling of the basin, broadly covering $3800 \mathrm{yr}$. between 131 the Late Neolithic and the early Middle Ages (5000 to 1200 cal BP). Sedimentological, geochemical, 132 micromorphological and malacological investigations were performed on two cores and supported 133 by AMS radiocarbon dating. Results were here synthetized and discussed with other regional climate 134 and palaeoenvironmental data for each archaeological period between the Late Neolithic and the 135 early Middle Ages, in order to provide a more comprehensive perspective of socio-environmental 136 interaction and human forcing of natural systems since the Mid-Holocene.

Figure 1. A) Location of study area, black line delineates Auvergne region; B) General view of study area from the summit of the Puy de Corent (location: see Fig. 1C, view direction: ESE). La Narse hydromorphic basin and its catchment are indicated

141 with white and red dashed lines respectively. Light blue dashed line indicates hypothetical position of former river course 142 (Pleistocene and Early Holocene), from cross sections and current topography (see Mayoral et al., 2018); C) 143 Geomorphological sketch of la Narse de la Sauvetat catchment (modified from Mayoral et al., 2018); D) Main soils of the 144 catchment (red dashed line) following Bornand et al., 1968 : a) lithosols and brown soils on basalts; b) Calcareous and 
146

147

148

149

150

151

152

153

154

155

156

157

158

159

160

161

162

163

164

165

166

167

168

169

170

Calcareous brown soils on gentle slopes; e) Clayey grey soils of marly depressions, hydromorphic and isohumic; f) Calcareous brown soils from thin residual terraces ; g) Gleyic soils from clayey alluvium of streams and marly lowlands.

\section{2-Materials and Methods}

\section{Coring and litho-stratigraphic analysis}

Three cores were retrieved from the basin in December 2014 using a Geotool GTR 790 corer with a diameter of $7 \mathrm{~cm}$. Drilling areas were selected after a preliminary survey consisting of c. 30 hand auger litho-stratigraphic logs distributed along several cross-sections (Mayoral et al., 2018). NAR2 (depth $230 \mathrm{~cm}$ ) was situated in the lower part of the depression, whereas NAR3 (depth $227 \mathrm{~cm}$ ) and NAR4 (depth $284 \mathrm{~cm}$ ) were located in a drier peripheral area (Fig. 1C and 2). NAR4 was not subject to multi-proxy palaeoenvironmental analysis and is therefore not presented in this work. Detailed lithostratigraphic and sedimentary description of NAR2 and NAR3 cores was performed (See Table 1 and Fig. 3), in order to refine the description of sedimentary units (SU) from previous work (Mayoral et al., 2018).

Figure 2. Selected stratigraphic cross-sections of the basin (P1 and P2, adapted from Mayoral et al., 2018) with location of cores NAR2 and NAR3 (see also Fig. 1C).

\section{Radiocarbon dating and age-depth modeling}

Radiocarbon database from the first study (Mayoral et al., 2018) was completed with 9 AMS radiocarbon dates in cores NAR2 and 3 (see Table 2). Two were performed in selected gastropod shells (Vallonia pulchella) in order to test if terrestrial species could locally provide accurate radiocarbon ages in the absence of other datable material. Other dates were performed on microcharcoal manually concentrated using a binocular microscope, after deflocculating sediment with sodium hexametaphosphate and sieving at 500 and $100 \mu \mathrm{m}$. Raw radiocarbon dates were calibrated with Calib 7.0 (Stuiver and Reimer, 1993) and IntCal13 calibration curve (Reimer et al., 
171 2013). Age-depth models (ADM) were built using smooth spline method under CLAM (Blaauw, 2010),

172 based on radiocarbon data and unambiguous stratigraphic correlations between cores (Fig. 3).

173 Sediment Accumulation Rate (SAR) was then calculated.

\section{Micromorphological analysis}

175 A half-section of NAR2 core was cut between 64 and $195 \mathrm{~cm}$ in 11 micromorphological blocks (see 176 Fig. 3). After induration, thin sections were made from these blocks at the OMEAA laboratory of UMR 1775600 EVS (University Lyon 2) following a common protocol (Guilloré, 1980). Thin section description 178 was performed using a Leica M80 binocular microscope (x2.5 to $\times 60$ ) and a Leica DMLP polarizing 179 microscope (x16 to $\times 400$ ), under Cross-Polarized Light (XPL) and Plane Polarized Light (PPL), and 180 according to state-of-the-art references (Delvigne, 1998; Loaiza et al., 2015; MacKenzie et al., 1982; 181 Scholle and Ulmer-scholle, 2003; Stoops, 2003). A Leica camera was used to take microphotographs 182 and measurements. Micromorphological features were semi-quantitatively recorded (see Fig. 4 to 6 183 and Table 3 in Supplementary Information (SI)) and interpreted on the basis of up-to-date reference 184 works (Macphail and Goldberg, 2018; Nicosia and Stoops, 2017; Stoops et al. 2010b). Micro-charcoal 185 was semi-automatically quantified using image analysis software (Aphelion Dev) and 186 microphotographs taken each centimeter under Oblique Incident Light (OIL) (Berger et al., 2016). 187 Reddish scoria particles, whose local sources are limited to the Puy de Corent slopes in the eastern 188 part of La Narse catchment (Bouiller, 1979), were manually counted and their surface measured each 189 centimeter with a binocular microscope in order to be used as a tracer of sedimentary sources.

190 X-Ray Fluorescence

191 X-Ray Fluorescence (XRF) measurements were performed in NAR2 and NAR3 cores using an Avaatech 192 XRF core-scanner (EDYTEM, Université Savoie Mont Blanc). Cores were analyzed with $5 \mathrm{~mm}$ 193 resolution under $10 \mathrm{kV}(1 \mathrm{~mA}, 10 \mathrm{~s})$ and $30 \mathrm{kV}(0.75 \mathrm{~mA}, 30 \mathrm{~s})$ beams generated by a Rhodium anode. 194 Results include detection in counts per second (cps) for $\mathrm{Al}, \mathrm{Si}, \mathrm{P}, \mathrm{S}, \mathrm{Cl}, \mathrm{K}, \mathrm{Ca}, \mathrm{Ti}, \mathrm{Cr}, \mathrm{Mn}, \mathrm{Fe}, \mathrm{Rh}, \mathrm{Cu}, \mathrm{Zn}$, 195 $\mathrm{Ga}, \mathrm{Br}, \mathrm{Rb}, \mathrm{Sr}, \mathrm{Y}, \mathrm{Zr}, \mathrm{Nb}, \mathrm{Mo}, \mathrm{Pb}$ and $\mathrm{Bi}$. A Principal Component Analysis (PCA) was performed using 
196

197

198

199

200

201

202

203

204

205

206

207

208

209

210

211

212

213

214

215

216

217

218

219

220

Xlstat software on selected elements of NAR2 (Fig. 8), in order to assess relationships between elements and with sedimentary units (Bajard et al., 2016; Birks \& Birks, 2006 ; Sabatier et al., 2010).

To improve the PCA interpretation and especially to refine the sedimentary source identification, we added 20 supplementary individuals (not contributing to the PCA) obtained from XRF analysis of a core situated in the top of the Puy de Corent (Fig. 1C). These individuals reflect the geochemical signature of a $100 \%$ volcanic soil and sediment (data from Mayoral, 2018). Elementary ratios were selected as palaeoenvironmental proxies based on PCA analysis, local geology and soils, lithostratigraphy, micromorphological analysis and sedimentological data, and following up-to-date references (e.g. Croudace and Rothwell, 2015).

\section{Sedimentological analysis}

Grain-size analysis was undertaken on NAR2 core using a Coulter LS230 granulometer. We analyzed contiguous $2 \mathrm{~cm}$-thick sediment slices of NAR2, between 30 and $230 \mathrm{~cm}$ (see Fig. 3). Data were then processed under Gradistat (Blott and Pye, 2001), and resulting statistical parameters (D50 and D99) were used to build a Passega (or CM) diagram (see Fig. 8) in order to identify hydro-sedimentary processes (Bravard and Peiry, 1999; Passega, 1977).

Magnetic susceptibility (MS) of NAR2 and NAR3 was measured using a Bartington MS2E meter. Four measurements were performed each $\mathrm{cm}$, and the mean value was retained in order to integrate signal variability (Dearing, 1999). Loss on ignition (LOI) was used to assess contents in organic matter (OM) and carbonates in both cores. We analyzed contiguous $2 \mathrm{~cm}$-thick sediment slices (see Fig. 3 ) of NAR2 $(30-230 \mathrm{~cm})$ and NAR3 $(54-227 \mathrm{~cm})$, following a standard two-step protocol (Heiri et al., 2001).

\section{Malacological analysis}

Malacological analysis was performed in both cores in order to assess the development of the structure of the vegetation cover and to reconstruct hydrological dynamics in the depression. We sampled contiguous $2 \mathrm{~cm}$-thick sediment slices (see Fig. 3 ) in NAR2 $(70-202 \mathrm{~cm}$, half-section) and NAR 3 (84-201 cm, full section). Samples were sieved at $500 \mu \mathrm{m}$ and studied under binocular microscope. 
221 When necessary, samples from the same SU were grouped in bigger sets (4 to $14 \mathrm{~cm}$, see Tables 4 222 and 5 in SI) in order to reach a significant number of shells, since at least 150 individuals per sample 223 were required to run a reliable statistical analysis (Evans, 1972). Samples comprising a boundary 224 between two SU were not analyzed. Determination of species was performed on the basis of 225 identification guides (Horsák et al., 2013; Kerney \& Cameron 2006; Welter-Schultes, 2012 ). 23 226 terrestrial and 14 freshwater species have been listed (Tables 4 and 5 in SI). On the basis of the 227 faunal lists, an analysis of the species composition of the malacological assemblage of each sample 228 was carried out and each species was assigned to an ecological group, which was defined in the light 229 of the habitats described in the species guides used for determination. Terrestrial species were 230 divided into four ecological groups (shade-demanding species, mesophile species, marshland species 231 and open-ground species) while freshwater species were combined in a single group (Fig. 9).

\section{$232 \quad 3$-Results}

\section{$233 \quad 3.1$ Stratigraphy and age-depth models}

234 Litho-stratigraphy of both cores is broadly similar, with some thickness and grain-size variability due 235 to lateral change of facies and position in the depression (see Figs. 1 to 3). Four Sedimentary Units 236 (SU) are concerned by multi-proxy analysis: SUIII.2-3, SUIII.1b, SUIII.1a and SUII.3. For a complete 237 description of NAR2 and NAR3 litho-stratigraphy, see Table 1. SU III.2-3 consists of grey silty clays, 238 including (in the core NAR2) two well-sorted and fining-upwards coarse sand levels. SUIII1.b is 239 composed of more or less dark grey silty clay with traces of pedogenesis: this layer is representative 240 of the locally extended hydromorphic and isohumic soils, so-called Limagne "dark earths" (Bornand 241 et al., 1968). SUIII.1a is similar to SUIII.1b, but has a more brownish color and includes several 242 oxidation mottles, indicating drier or more fluctuating hydrological conditions. Finally SUII.3 is 243 composed of black and very dark grey silty clays, rich in non-degraded vegetal debris, suggesting 244 deposit under palustrine conditions (Mayoral et al., 2018). 


\section{NAR2}

Description (Munsell color, grain size, inclusions, pedofeatures)

7 2,5Y4/2 Silty clay with macrocharcoal and OM remains, few fine sands, bioturbation 8 (current topsoil)

2,5Y4/2 Silty clay to clayey silt, abundant OM remains, few fine sands, bioturbation (roots)

2,5Y4/2 Silty clay, some fine sands, few small charcoal, rootlets

$2,5 Y 4 / 2$ Clayey silt, pale yellow inclusions (diatomite), small yellowish brown oxidation

1 mottles, small charcoal, some fine to medium sands, rare malacoremains

$13,5 Y 4,5 / 2$ Clayey silt, rare sands, abundant pale yellow inclusions (diatomite), few

18 mall yellowish brown oxidation mottles, some malacoremains

$12,5 Y 5 / 2$ Silty clay, darker dots, some malacoremains

$12,5 \mathrm{Y} 5 / 2$ Silty clay, sparse fine to medium sands, darker inclusions from underlying unit,

1 irregular inferior limit, abundant malacoremains

$15^{5} 4 / 1$ Silty clay, sparse fine sands, darker inclusions from underlying unit, incipient

1 gubangular to granular aggregation, abundant malacoremains

2,5Y2/0 Silty clay, brown inclusions from underlying unit, few fine sands, small organic

2 debris and abundant $\mathrm{OM}$, incipient granular to crumbly aggregation, abundant

2 malacoremains.

$2 \sqrt{5}$ Y4/1 Silty clay, several black inclusions from overlying unit, several small yellowish

2 Brown oxidation mottles, few malacoremains.

2 5Y4/1 Silty clay, rare black inclusions from overlying units, rare oxidation mottles, rare

2 malacoremains

25 Y4/1 Silty clay,rare fine sands, rare malacoremains

25 Y/1 Silty clay, incipient granular aggregation to the base, few malacoremains

$25 \mathrm{Y} 3,5 / 1$ Silty clay, incipient crumbly aggregation, several malacoremains,

25 Y3/1 Silty clay, incipient crumbly aggregation, abundant malacoremains

2 FY3/1 Silty clay, incipient crumbly aggregation (top), abundant malacoremains

$3 / 5 Y 4 / 1$ Silty clay, sparse fine sands, abundant darker mottles from overlying unit

3 5Y4/1 Slightly silty clay, few dark mottles, one dark lamination, some sparse fine sands

3 SY4/1,5 Silty clays, several fine to medium sands, several small oxidation mottles,

3 Prregular contact with underlying unit. One dark lamination.

3 \$ Y $4 / 1,5$ Fine to coarse sands, poorly rounded grains (limestone, basalt, quartz). Fining

3 3ipwards sorting. Few silts and clays. Irregular top and base.

35 Y4/1 Silty clays abundant sparse fine to coarse sands (limestone, basalt, quartz), rare 3 malacoremains.

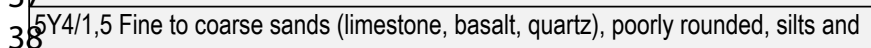
3 clays. Fining upwards sorting (poorly marked). One angular basaltic gravel at the base.

3 YY4,5/1 Silty clay, some sparse fine sands

$4 / 5 Y 4,5 / 1$ Silty clay, with intercalations of $5 Y 6 / 2$ heavy clay, including oxidation mottles.

4 Sparse fine to coarse sands

4 5Y6/2 Heavy clay with oxidation mottles and darker mottles from upper units

4 (3bioturbation?). Rare and sparse fine sands

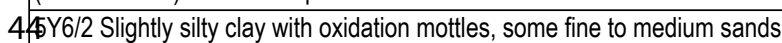

45 Y $6 / 2$ Heavy clay with rare oxidation mottles, rare fine to medium sands

$4 \widehat{5 Y 6 / 2 ~ S l i g h t l y ~ s i l t y ~ c l a y, ~ b i g ~ o x i d a t i o n ~ m o t t l e s, ~ s p a r s e ~ f i n e ~ t o ~ m e d i u m ~ s a n d s ~}$

$45 \mathrm{Y} 6 / 2$ Heavy clay, rare oxidation mottles, sparse fine to medium sands

48

49

50

51

52

53

54

55

56

57

58

59

60

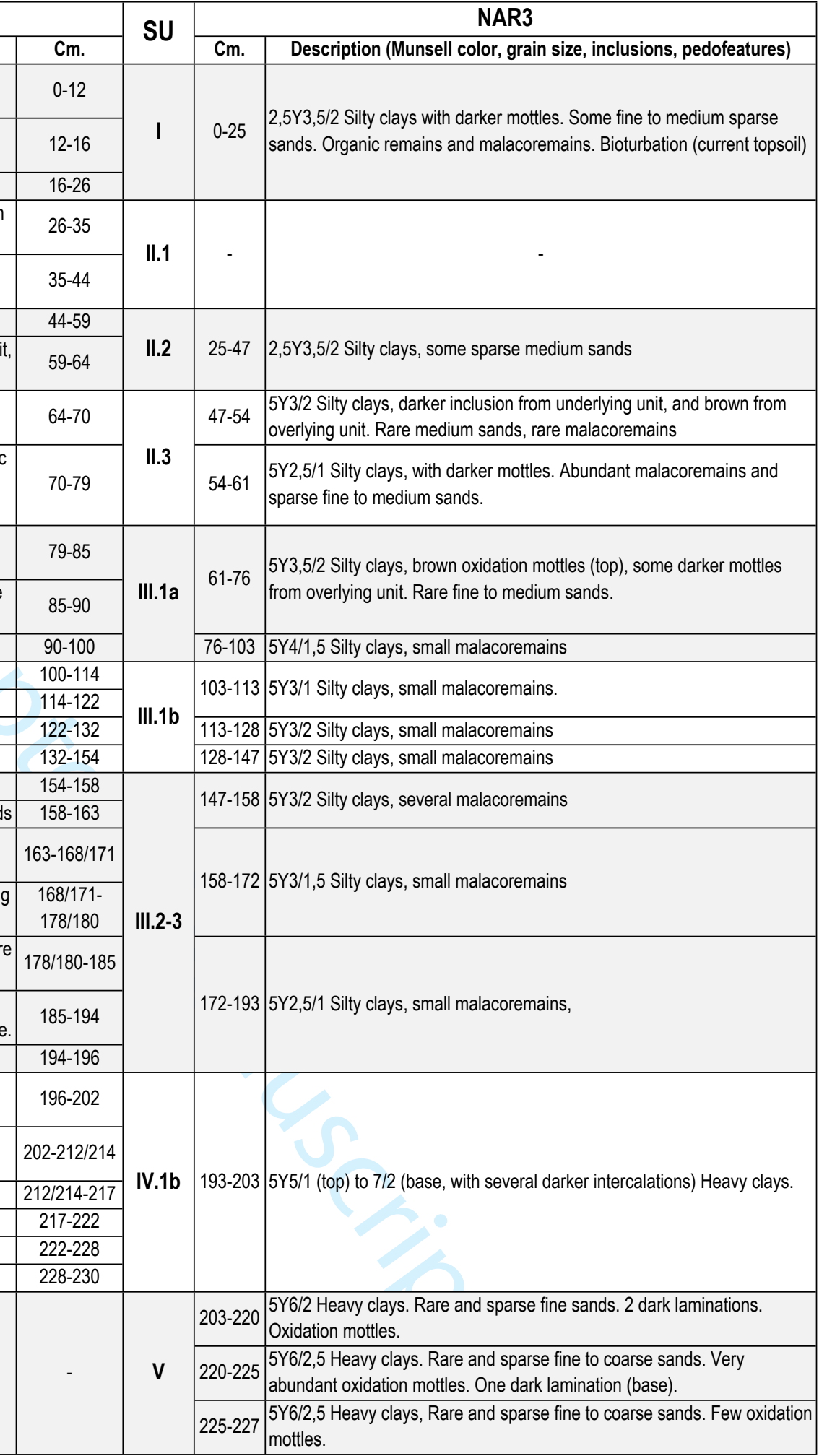

246 The radiocarbon database includes 14 dates distributed within the two cores and performed mainly

247 on charcoal (Table 2). The two dates on gastropod shells were rejected because they provided

248 significantly older results than charcoal, clearly inconsistent with the chrono-stratigraphic

249 framework. The Age-Depth Model (ADM) constructed for NAR2 (smooth spline) was extrapolated to 
$250230 \mathrm{~cm}$ and SAR was calculated, showing a peak c. 2200-2300 cal BP (Fig. 3). Using radiocarbon and

251 stratigraphic correlations with NAR2 (SUIV.1b and SUII.3), a less robust (especially under $150 \mathrm{~cm}$ ) but 252 nevertheless satisfactory ADM was also constructed for NAR3. SAR in NAR3 shows a disproportionate 253 peak, between two comparable dates (Table 2), suggesting a virtually instantaneous deposit such as 254 flood overbank deposits or anthropogenic backfill linked to nearby Roman archaeological remains 255 (Fig. 1 and 2). The best age-model estimation from both models was used to discuss multi-proxy 256 analysis results.

257 Figure 3. Litho-stratigraphy, stratigraphic correlations, sampling and age-depth model of NAR2 (left) and NAR3 (right) cores.

258

259

260

261

262

263

264

265

266

267

268

269

270

271

272

273

274

275

276

277

278

279 


\begin{tabular}{|c|c|c|c|c|c|c|c|}
\hline № & Core & Depth (cm) & Lab Code & Material & ${ }^{14} \mathrm{C}$ yr. BP & Cal BP (median, 2 $\sigma$ ) & Cal BC/AD (median, 20) \\
\hline 1 & NAR2 & $38-40$ & Poz-86197 & Microcharcoal & $485 \pm 30 \mathrm{BP}$ & $522 \pm 21$ & $1428 \pm 21$ cal AD \\
\hline 2 & NAR2 & $70-72$ & Poz-71623 & Microcharcoal & $1505 \pm 30 \mathrm{BP}$ & $1418 \pm 100$ & $532 \pm 100 \mathrm{cal} A D$ \\
\hline 3 & NAR2 & $76-78$ & Poz-86198 & Microcharcoal & $1540 \pm 40 \mathrm{BP}$ & $1439 \pm 89$ & $511 \pm 89 \mathrm{cal} \mathrm{AD}$ \\
\hline 4 & NAR2 & $106-108$ & Poz-71624 & Microcharcoal & $2035 \pm 35 \mathrm{BP}$ & $2006 \pm 106$ & $56 \pm 106 \mathrm{cal} \mathrm{BC}$ \\
\hline 5 & NAR2 & $142-144$ & Poz-71625 & Microcharcoal & $2410 \pm 40 \mathrm{BP}$ & $2524 \pm 176$ & $574 \pm 176$ cal BC \\
\hline 6 & NAR2 & $160-162$ & Beta-434189 & Microcharcoal & $2460 \pm 30 \mathrm{BP}$ & $2537 \pm 171$ & $587 \pm 171 \mathrm{cal} \mathrm{BC}$ \\
\hline 7 & NAR2 & $183-184$ & Poz-86199 & Microcharcoal & $3415 \pm 30 \mathrm{BP}$ & $3699 \pm 120$ & $1749 \pm 120 \mathrm{cal} \mathrm{BC}$ \\
\hline 8 & NAR2 & $190-192$ & Poz-86200 & Microcharcoal & $3910 \pm 30 \mathrm{BP}$ & $4335 \pm 86$ & $2385 \pm 86$ cal BC \\
\hline 9 & NAR2 & $196-200$ & Poz-86201 & Microcharcoal & $4280 \pm 60 \mathrm{BP}$ & $4831 \pm 206$ & $2881 \pm 206 \mathrm{cal} \mathrm{BC}$ \\
\hline 10 & NAR3 & $98-100$ & Poz-86203 & Microcharcoal & $1540 \pm 50 \mathrm{BP}$ & $1437 \pm 102$ & $513 \pm 102 \mathrm{cal} A D$ \\
\hline 11 & NAR 3 & $114-120$ & Poz-103585 & $\begin{array}{l}\text { Vallonia pulchella } \\
\text { shells }\end{array}$ & $2425 \pm 30 B P$ & $2526 \pm 172$ & $576 \pm 172 \mathrm{cal} \mathrm{BC}$ \\
\hline 12 & NAR3 & $120-122$ & Poz-86204 & Microcharcoal & $1930 \pm 35 \mathrm{BP}$ & $1901 \pm 88$ & $49 \pm 88 \mathrm{cal} \mathrm{AD}$ \\
\hline 13 & NAR3 & $130-132$ & Poz-86205 & Microcharcoal & $2010 \pm 30 \mathrm{BP}$ & $1963 \pm 78$ & $13 \pm 78 \mathrm{cal} \mathrm{BC}$ \\
\hline 14 & NAR 3 & $174-181$ & Poz-103586 & $\begin{array}{c}\text { Vallonia pulchella } \\
\text { shells }\end{array}$ & $6480 \pm 50 B P$ & $7379 \pm 98$ & $5429 \pm 98 \mathrm{cal} \mathrm{BC}$ \\
\hline
\end{tabular}

281

282

$283 \quad 3.2$ Micromorphology

284 Detailed micromorphological descriptions can be found in Table 3 in SI. The key features used to

285 define micromorphological units (named MI to MVII) were semi-quantitatively recorded in Fig. 6.

286 Units MVII and MV (195-188 and 178-166 cm) are formed by roughly sorted coarse to fine alluvial

287 sand with fining-upwards sorting. Sand is rich in carbonated and volcanic grains (basalt with analcime

288 crystals and scoria, see Fig. 4), and rounded fragments of tuffaceous/pisolithic coatings and

289 biospheroids. These fragments together with some organic remains (chiefly vegetal tissues, bone or

290 charcoal) and inherited pedosedimentary aggregates, indicate a polyphased genesis of these sandy 
291 layers. Both are likely the result of an intense hydro-sedimentary event that eroded soils and

292 riverbed deposits of the catchment, separated by a phase of incipient soil formation (MVI).

Unit MIV (172-152 cm) matrix is made of silty clays with few coarse particles, and micromorphological features (microstructure, pedofeatures) broadly indicate more mature soil development than in previous phases. Reduced porosity, few biospheroids and presence of calcite and manganese nodules suggest a massive soil, with fluctuating water table level and short but repeated water saturations of soil (Courty et al. 1989; Durand et al., 2010; Freytet and Verrecchia, 1998; Lindbo et al. 2010; Zamanian et al., 2016). Abundance of mite droppings (Fig. 4 and 6) instead

The top of the unit presents striking micromorphological differences with the underlying units, such as platy microstructure, increased porosity (vughs, small rootlets channels), calcitic earthworm 
320 biospheroids and more abundant organic remains including micro- and macrocharcoal (Fig. 4 and 6).

321 In addition, some small aggregates with striated b-fabric are likely fragments of a slaking crust from

322 superficial soil palaeohorizons (Fig. 4). Taken together, these features clearly indicate a major soil

323 disturbance at the summit of unit MIV that might result from agricultural activities and use of fire to

324 clear the ground (Adderley et al., 2010; Deák et al., 2017a; Jongerius, 1970; Macphail et al., 1990;

325 Pagliai and Stoops, 2010a; Spek et al., 2003).

326 MIII unit $(148-100 \mathrm{~cm})$ shows confirmation of the new soil dynamics already outlined at the top of

327 MIV, namely agricultural activities probably involving use of fire. MIII has a silty clay matrix with rare

328 coarse grains, and well-developed blocky subangular to granular microstructure (Fig. 6). Intrapedal

329 porosity is dominated by small grass channels. The lack of intra-aggregate biogenic macro-porosity

330 despite abundant organic matter (OM) and biospheroids, and lack of true granular or excremental

331 microstructures, strongly supports human-induced reaggregation by repeated ploughings (Adderley

332 et al., 2010; Macphail et al., 1990 ; Spek et al., 2003). Absence of coarse textural features such as

333 silty-clay coatings is not critical here, since they are not a sine qua non condition for cultivated

334 horizons (Deák et al., 2017a; Usai, 2001), especially in fine-textured carbonated rocks context: in

335 these cases, alternative indicators are charcoal increase, loss in gastropod diversity (Macphail and

336 Goldberg, 2018; Whittle et al., 1993) and/or loss of micro-arthropods population due to soil

337 disturbance (Jeffery et al., 2010).

338 Vegetal debris, fine organic matter and biospheroids, and especially microcharcoal are clearly more 339 abundant than observed before and are distributed homogeneously within the unit (Fig. 6). These 340 features indicate the continuous development of a relatively homogeneous organo-mineral $\mathrm{A}$ 341 horizon (Adderley et al., 2010; Durand et al. 2010; Gerasimova and Lebedeva-Verba, 2010; Stoops et 342 al., 2010a). Resulting soil profile could be described as isohumic with cumulic and slightly 343 hydromorphic processes. 
344 Redox pedofeatures of MIII are of limited intensity and vertically heterogeneous, indicating that they

345 corresponded to repeated flooding of the depression with variable frequency and duration (Kovda 346 and Mermut, 2010 ; Lindbo et al., 2010). Together with other pedofeatures (erosion markers, 347 carbonates, microstructure) these redox indicators allowed us to distinguish four alternating sub348 phases within MIII (see Fig. 6). Micromorphological indicators (microstructure, calcite and iron 349 nodules, iron hypocoatings, spores, see Fig. 4) suggest that MIII.4 and MIII.2 were affected by more 350 intense watertable fluctuations with repeated and long-term floods, alternating with dry phases 351 (Fedoroff and Courty, 2002; Kovda and Mermut, 2010; Lindbo et al., 2010; Stoops et al., 2010a). 352 Hydrological conditions were probably drier and more stable for phases MIII.3 and MIII.1, less 353 affected by seasonal floodings (few calcite and iron nodules). Additionally, micromorphological 354 evidence (macrocharcoal, pedosedimentary aggregates) indicates increased soil erosion and fires 355 during MIII.3 (Adderley et al., 2010 ; Fedoroff et al. 2010).

356 MII unit $(100-79 \mathrm{~cm})$ is broadly comparable to MIII. Increasing soil erosion in the catchment is 357 suggested by more abundant volcanic mineral fraction and well-rounded calcite biospheroids. More 358 abundant organic matter features (especially macrocharcoal) and presence of some incipient 359 microlaminated clay coatings (partly oriented, limpid to dusty) in underlying unit (MIII) point to 360 increasing soil disturbance and illuviation, probably connected to more intensive agricultural activity 361 (Kühn et al., 2010) in a context of general low accretion and soil profile stability. Atypical redox 362 features distribution (iron hypocoatings at the top, and manganic nodules at the base) together with 363 other micromorphological features, suggest a broadly drier phase. This was subsequently followed by 364 very wet conditions probably due to floods during MI deposition (see below), similarly to paddy soil 365 redox patterns (Stolt and Lindbo, 2010). 
Figure 5. Selected micromorphological features from upper NAR2 (Micromorphological Units MIII to MI, see text and Fig.6). A) Orthic tuffaceous concretion, from aggregation of smaller micritic elements and pseudomorphs (MI, N204, XPL-Crossed Polarized Light). B) Tuffaceous calcite capping. Note dark micromass, rich in organic matter (MI, N204, XPL). C) Orthic calcite nodule in a dark cristallitic to isotropic micromass (MI, N204, XPL). D) Micromass rich in calcitic grains strongly bioturbated and reorganized by biological activity (MI, N204, XPL). E) Complex microstructure, subangular with granular substructure or crumbly subangular (MI, N204, transmitted light). F) Diatoms embedded in carbonate-rich micromass (MI, N204, PPLPlane Polarized Light). G) Characeae oogon. Note the two different types of micromass: brown, clayey, rich in organic fragments and microcharcoal (base) vs. massive micritic-microsparitic micromass (top) (MI, N204, XPL). H) Iron and micritic hypocoatings around a chamber and fissural to canalicular voids (MIII, N208, XPL). I) Subangular blocky microstructure of an organo-mineral unit (MIII, N207, transmitted light). J) Iron hypocoating and biospheroid, note silty clay micromass rich in microcharcoal and small organic fragments (MII, N205, PPL). K) Granular microstructure of a organo-mineral unit, note partial collapse of porosity due to secondary clogging (MIII, N210, transmitted light). L) Silty clay matrix highly impregnated by oxidized iron, and injection of matrix aggregates (rich in organic matter) from upper layers (MII, N205, XPL). M) Concentration of micritic to microsparitic calcite in the matrix (and in voids), some evolving to nodules (MIII, N208, XPL). N) Calcite nodule (micritic to microsparitic) in development by impregnation of the matrix (MIII, N209, XPL). O) Small bone fragment embedded in a silty clay matrix with microcharcoal and organic microdebris (MII, N205, PPL).

MI $(79-64 \mathrm{~cm})$ presents micromorphological features radically different from all other units. The matrix is globally very cristallitic, extremely rich in brown to black organic fragments with frequent microsparitic to sparitic calcite nodules (orthic), and abundant bio-mineral microfossils (ostracods, characeae pseudomorphs and oogons and tuffaceous concretions, see Fig. 5 and 6) indicating aquatic conditions (Nicosia and Stoops, 2017; Scholle and Ulmer-scholle, 2003). This unit can globally be interpreted as an aquatic environment with marked palustrine features. Very abundant and rounded micro- and macrocharcoal fragments suggest fires and erosion on the slopes of the catchment.

Detailed micromorphological analysis enabled us to discern a threefold structure within MI unit (Fig.

6). MI.3 is characterized by abrupt development of palustrine conditions (very abundant organic matter) above the MII relatively dry palaeosoil. These new conditions are more probably the result of drainage deterioration and strong and permanent flooding than of a rise of groundwater-level (see unit MII features). Peak of macro- and microcharcoal (Fig. 6) and inclusion of soil aggregates from MII indicate strong and local soil erosion during this process. Water level rose during phase MI.2 and conditions became lacustrine (disappearance of pedogenic features), with strong authigenic 
397 diatoms, see Fig. 5). Finally water level decreased slightly in MI.1, as suggested by reoccurrence of 398 channels and biospheroids, more organic micromass with charcoal, and less calcite nodules and 399 tuffaceous concretions. However, posteriority of these "drier" pedofeatures due to later phases of 400 total emersion and erosion (not analyzed here) cannot be excluded. 


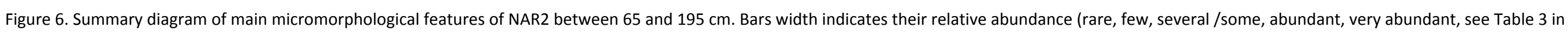
Supplementary Information), or alternatively their development degree. Scoria and microcharcoal are quantified using image analysis (IA). C/F: Coarse/Fine ratio, here 20 $\mu$ m. 


\section{$405 \quad 3.3$ Geochemistry and sedimentology}

406 The Sedimentary Units (SU) are well differentiated on the Passega (or CM) diagram of NAR2 (Fig. 8B).

407 Most samples are poorly sorted (i.e. far from $\mathrm{C}=\mathrm{M}$ line) due to common coarse particles embedded in 408 abundant fine matrix. This is certainly due to long-term pedoturbation of most part of this low409 aggradation pedo-sedimentary sequence, making it difficult to understand "pure" sedimentary 410 processes. SUII.1, II.2-3 and II.3 probably refer to very low energy sedimentary processes 411 (decantation phase) mixed with relatively rare and weak detrital inputs (graded to uniform 412 suspension), likely formed under aquatic conditions. At the opposite, SUIII (III.1a, $1 \mathrm{~b}$ and $2-3$ ) has a 413 CM signature implying variated processes of transport and deposition (decantation, graded 414 suspension and rolling). Excepting sandy layers, deposits have a broadly fine but highly variable grain415 size, which is consistent with a low-energy alluvial-palustrine plain with reduced aggradation, 416 implying permanent pedoturbation and homogenization of flood deposits.

417 The XRF elementary signals obtained for NAR2 and 3 are globally consistent with main stratigraphic 418 changes and with sedimentological indicators (Fig. 7A and B). Magnetic Susceptibility (MS) and D50 419 are interrelated and correlated with $\mathrm{Fe}, \mathrm{Si}$ and $\mathrm{Ti}$ (except in sandy layers of NAR2), and with $\mathrm{Fe}, \mathrm{Zr}$ 420 and $\mathrm{Rb}$ in NAR3. Organic matter (OM) content is inversely correlated to carbonate content in both 421 cores (see Fig. 7). Variables are well differentiated in the PCA on selected elementary signals of NAR2 422 (Fig. 8A), where the first 2 components count for $78.6 \%$ of the variability. The main axis (64.9\%) 423 represents the opposition between allochtonous detrital inputs (positive scores, terrigenous 424 elements) and authigenic elements production under wet or aquatic conditions (negative scores, 425 mainly $\mathrm{Ca}$ and $\mathrm{Sr}$ carbonates and $\mathrm{Mn}$ ). The second axis represents the balance between siliciclastic 426 materials (positive scores: $\mathrm{Si}, \mathrm{Al}$ ) and volcanic materials (negative scores: $\mathrm{Zr}$, Ti). SUs are well 427 differentiated in the distribution plot following main axes of the PCA (Fig. 8A). SUI to SUIII show 428 mainly volcanic sediment influence, SUIII being the more detrital unit in the sequence (excepting 429 sands). The gradual shift from SUIII to SUII.1 (from positive towards negative values of main axis) 430 strongly suggests drainage degradation and installation of aquatic conditions. 
431 Five endmembers could therefore be identified depending on their geological sources and authigenic 432 or allochthonous origins. A first one includes $\mathrm{Zr}$ and $\mathrm{Ti}$, which are especially abundant in volcanic 433 rocks (Mielke, 1979 ; Salminen et al., 2005) and likely come from volcanic materials of surrounding 434 reliefs. The position of 20 supplementary individuals (red squares, not contributing to the PCA, see 435 methods) obtained from XRF analysis of a core on volcanic-derived clays (Mayoral, 2018) confirmed 436 this interpretation (Fig. 8A).

$437 \mathrm{Si}, \mathrm{Al}$ and $\mathrm{Pb}$ are more abundant in felsic materials (Mielke, 1979; Wedepohl, 1978) and are therefore 438 suggestive of sedimentary inputs derived from silt-rich marls, very abundant in Limagne lowlands. 439 Finally Fe and $\mathrm{Zn}$, more abundant in volcanic rocks but also present in felsic materials, form together 440 with $\mathrm{Rb}$ an intermediate endmember, indicating mixed inputs or a source from a residual terrace of 441 the Allier river, which borders the northern margin of the depression (Fig. 1B and C). Ca and Mn form 442 a typical chalco-manganic endmember related to wet conditions and authigenic carbonate formation 443 (Salminen et al., 2005; Wedepohl, 1978). The last endmember is formed by Sr alone, isolated from Ca 444 and $\mathrm{Mn}$ due to its higher abundance in volcanic rocks (Mielke, 1979).

445 Based on these data, on geochemistry of rocks and soils from the study area, and on existing 446 literature, we interpreted the local palaeoenvironmental significance of selected elementary ratios. $447 \mathrm{Zr}$ content is relatively high in coarse sediment as it is related to the presence of detrital heavy 448 minerals (zircon, sphene), and is lower in finer sediment where heavy minerals are scarcer. By 449 contrast $\mathrm{Rb}$ is often higher in finer fraction of sediment due to its very strong sorption by clay 450 minerals (Salminen et al., 2005). In NAR2 and NAR3 cores, $\mathrm{Zr} / \mathrm{Rb}$ ratio appears positively correlated 451 to D50 of the sediment, both in its fine $(<50 \mathrm{um})$ and coarse ( $>50 \mathrm{um})$ fractions (see Fig. $12 \mathrm{~B}$ in 452 Supplementary Information). Consequently we propose to interpret $\mathrm{Zr} / \mathrm{Rb}$ as a grain-size proxy in our 453 cores.

$454 \mathrm{~Pb}$ content in European soils and floodplain sediments is related to two main factors: lithology 455 (natural $\mathrm{Pb}$ mineralisations) and anthropogenic contamination, i.e. historical mining or industrial 
456 activities (Salminen et al., 2005). Calcareous and volcanic rocks, such as those found in La Narse de la 457 Sauvetat catchment, are not a significant source of lithogenic Pb. Additionally, considering the very 458 small size of the catchment and its uncomplicated geology, lithogenic Pb fluxes can be assumed to be 459 more or less constant in the sedimentary record analyzed in NAR2 and NAR3, and anomalous Pb 460 enrichments are certainly of anthropogenic origin. A simple way to discriminate signal of 461 anthropogenic $\mathrm{Pb}$ from the lithogenic $\mathrm{Pb}$ background is normalization using a lithogenic and 462 chemically stable trace element (Arnaud et al., 2004, 2006). Therefore we propose to use $\mathrm{Pb} / \mathrm{Rb}$ as a 463 potential indicator of anthropogenic $\mathrm{Pb}$ contamination (and therefore metallurgic activity) in La 464 Narse de la Sauvetat sedimentary record, especially when ratio peaks appear dissociated from 465 detrital inputs proxies.

466 Fe is in general terms much more abundant in volcanic than in sedimentary rocks (Salminen et al., 467 2005), and consequently also in soils developed in volcanic materials (Legrand et al., 2007). 468 Geochemical studies in the Sarliève palaeolake catchment, also situated in southern Limagne and 469 largely sharing lithology and superficial formations with La Narse de la Sauvetat catchment (Bornand 470 et al., 1968; Bouiller, 1979; BRGM, 1973), show that local volcanic soils and rocks were Fe-enriched, 471 and clearly distinguishable from Ca-enriched soils developed on Limagne calcareous bedrock 472 (Fourmont et al., 2009). Within La Narse catchment, soils and fine sediment from the top of the Puy 473 de Corent (i.e. exclusively derived from volcanic rocks. See Fig. 1), show much lower values of Ca and 474 higher values of Fe (and hence significantly higher Fe/Ca ratio) than samples from NAR2 and NAR3, 475 situated in calcareous lowlands (see Fig. 12A in Supplementary Information -data from Mayoral, 476 2018-). Then, we propose to use $\mathrm{Fe} / \mathrm{Ca}$ to trace fine detrital inputs derived from erosion of 477 surrounding volcanic soils and surficial formations into La Narse Basin.

Figure 7. A) Selected elements and sedimentological data for NAR2. Values are in $10^{-5} \mathrm{SI}$ (Magnetic Susceptibility-MS-) and in counts per second (CPS) for the XRF. B) Selected elements and sedimentological data for NAR3. 
Figure 8. A) PCA biplot of selected geochemical variables according to dimensions 1 and 2, individuals are distributed by

Sedimentary Unit. Note supplementary individuals (red squares, data from Mayoral et al., 2018). B) Passega or C-M diagram of NAR2 with grain-size data by Sedimentary Unit. Grey area represents reference C-M diagram by Passega (1977).

\subsection{Malacology}

Seven environmental phases were reconstructed in NAR2 (phases $2 \mathrm{~A}$ to $2 \mathrm{G}$ in Fig. 9). In phase $2 \mathrm{~A}$ $(202-194 \mathrm{~cm})$ freshwater species count $50 \%$ of the total number of individuals. In the terrestrial fauna, shade-demanding molluscs are scarce (Fig. 9A). In phase 2B $(194-170 \mathrm{~cm})$ freshwater species decrease to $30 \%$ while proportions of shade-demanding species increase. Whether this ecological group shows its highest proportions of the whole core, the species from this group are not restricted today to forest environments and may have lived in tall grass patches in Limagne plain. The proportions of freshwater species increase in phase $2 \mathrm{C}(170-158 \mathrm{~cm})$ and despite a small number of shells, strong differences are highlighted in the ecological composition of the molluscan assemblage attributed to this phase with decreasing proportions of shade-demanding species (Fig. 9A). The 2D phase $(158-142 \mathrm{~cm})$ is characterized by a strong dominance of open-ground species, which represent $60 \%$ of the total number of individuals. Vallonia pulchella, which lives today in wet grassland environments, is the most abundant species (Table 4 in Supplementary Information-SI-). In addition, freshwater species represent only $20 \%$ of the assemblages (Fig. 9A). Galba truncatula is the main species within this group (Table 4 in SI). Its ability to survive dry episodes (Horsák et al., 2013) suggests a phase of contraction of the body of water in the depression and its replacement by wet grasslands. During the phase 2E $(142-100 \mathrm{~cm})$, freshwater species increase up to $60 \%$ (Fig. 9A). Galba truncatula and Anisus leucostoma dominance suggest seasonal incursions of water in the sampled locus (Welter-Schultes, 2012). In the terrestrial molluscan fauna, Vallonia pulchella is still the dominant species, and this taxon from wet grassland is supported by a diverse set of marshland species (Table 4 in $\mathrm{SI})$. The phase $2 \mathrm{~F}(100-80 \mathrm{~cm})$ is characterized by a dramatic decrease in freshwater species proportions (Fig. 9A). The freshwater species that are able to survive short-term dry episodes sharply decrease in abundance (Table 4 in $\mathrm{SI}$ ), which indicates a long-lasting depletion of 
508 the water body in the depression. In the terrestrial molluscan fauna, this environmental 509 development is discernible in the decreasing proportions of marshland species (Fig. 9A) and in the 510 replacement of the wet grassland species Vallonia pulchella by Vallonia excentrica (Table 4 in SI), 511 characteristic of drier open-ground habitats (Welter-Schultes, 2012). Finally, the phase $2 \mathrm{G}(78-70 \mathrm{~cm})$ 512 is strongly dominated (more than $70 \%$ ) by a diverse set of freshwater species (Fig. 9A). The main 513 species of this group is Gyraulus crista (Table 4 in $\mathrm{SI}$ ), which is characteristic of permanent and calm 514 small water bodies with rich vegetation (Welter-Schultes, 2012).

515 In the core NAR3, the full core was dedicated to malacological analysis. As a result, the volume of 516 analyzed sediment was more important, which resulted in more abundant assemblages than in the 517 core NAR2. However, as the volume of sediment analyzed was limited due to the core sampling 518 method, some samples had to be merged to ensure a sufficient number of individuals to carry out a 519 statistical analysis. Five environmental phases were reconstructed (3A to 3E). The phase 3A (201-181 $520 \mathrm{~cm}$ ) is dominated by species of open-ground habitats, mostly by Vallonia pulchella (Fig. 9B). In the 521 phase 3B (181-140 cm), V. pulchella is still the main species but the proportions of species living in 522 marshland habitats increase, which indicates wetter environmental conditions. During the phase $3 \mathrm{C}$ 523 (140-114 cm), marshland species show decreasing proportions while percentages of species of open524 ground environment increase (Fig. 9B). Whether $V$. pulchella remains the most common species 525 within this group, the development of $V$. excentrica reflects the presence of a distinctly drier open526 ground habitat. In phase 3D (112-104 cm), freshwater malacofauna significantly increase up to $40 \%$ 527 of the total (Fig. 9B). The dominance of $G$. truncatula within this group suggests a seasonally stagnant 528 water body with a damp grassland developed in the margin according to the terrestrial fauna 529 composition. Finally, phase $3 E(103-84 \mathrm{~cm})$ is characterized by a sharp increase in freshwater species 530 up to $80-90 \%$ (Fig. 9B). The dominance of G. crista within this group (Table 5 in SI) reflects a quiet and 531 permanent water flow with rich vegetation. 
533

534

535

536

537

538

539

540

541

542

543

544

545

546

547

548

549

550

551

552

553

554

\begin{abstract}
Figure 9. Diagrams of specific composition of molluscan assemblages A) NAR2 B) NAR3. Contiguous $2 \mathrm{~cm}$-thick sediment samples were grouped in bigger sets when necessary in order to reach a significant number of shells. Species are classified by ecological affinities and by order of occurrence.
\end{abstract}

\section{4-Discussion}

\subsection{Late Neolithic (end of Mid Holocene period)}

During the Late Neolithic (5000-4150 cal BP, phases N2.1 and N3.1 in Fig. 10, see also Fig. 11), after a lacustrine phase (see Mayoral et al. 2018), the basin was re-connected to the local drainage system and developed in a hydromorphic plain ( $\mathrm{Mn}$ peak at the base of both cores, Fig. 7). Redox conditions were contrasted: the downstream area (NAR2) was still partly aquatic according to malacological assemblages, and received detrital inputs from marly slopes of the Puy de Corent (high D50 and $\mathrm{CaCO})$. In the upstream sector (NAR3) higher organic matter (OM) values and malacological data suggest wet grasslands with more developed soils and oscillating watertable (Fig. 10 and 11). Here coarser detrital inputs from volcanic soils of the western catchment were predominant (higher MS, $\mathrm{Zr} / \mathrm{Rb}$ and $\mathrm{Fe} / \mathrm{Ca}$ values).

Relative openness and diversity of landscapes indicated by malacological assemblages suggest local transformations by Late Neolithic societies despite these wet conditions in the depression. This rough picture is consistent with archaeological evidence for this period: findings are very scarce at a regional level, however they indicate a preference for hillslopes and foothills and a reduced settlement density in Limagne lowlands during the Late Neolithic, maybe because of drainage deterioration (Ballut and Argant, 2004; Daugas and Raynal, 1989; Raynal et al., 2003; Trément, 2011). 


\section{$555 \quad 4.2$ Early to Middle Bronze Age}

556 Early and middle Bronze Age (4150-3250 cal BP, phases N2.2-3-4 and N3.2A in Fig. 10, see also Fig.

557 11) are characterized by a strong increase in hydro-sedimentary activity in the basin. In detail, the 558 period is tripartite: two high-energy alluvial phases (sands) covering the bottom of the basin (see $559 \quad$ Figs. 2 and 3), separated by a lower energy phase (sandy clays).

560 The first high-energy deposit was dated at $4464 \pm 97 \mathrm{cal}$ BP. It was associated with eroded soils from 561 surrounding volcanic slopes (scoria and nepheline observed in thin section) and from the marly 562 lowlands, but also with erosion of tuffaceous formations from local riverbeds, probably deposited 563 during previous hydro-climatic stability phase. This event was followed by a low-energy hydro564 sedimentary phases, dominated by fine volcanic inputs (higher Fe/Ca ratio, Fig. 10) together with an 565 incipient soil development from c. 3850 to 3450 cal BP (weak aggregation and pedofeatures, slightly 566 more organic matter). A second high-energy hydro-sedimentary episode occurred c. 3450 cal BP, also 567 eroding both soils and riverbed formations.

568 Radiocarbon ages of these two high-energy alluvial phases, similarity with contemporaneous 569 dynamics observed in the Rhone valley (Berger et al., 2007) and consistency with previous studies in 570 Limagne lowlands (Ballut, 2001; Ballut and Guichard, 2005; Trément, 2011; Vital, 2004) indicate that 571 they certainly had a climatic trigger. The first phase was likely associated with the $4.2 \mathrm{kyr}$. BP climatic 572 event, already documented in eastern and south-eastern French regions (Brisset et al., 2013; Carozza 573 et al., 2015; Magny, 2004). The chronological offset of c. 150-200 yr. (Walker et al., 2019) is likely due 574 to slightly older ages provided by floated charcoal in sandy layers. The second phase was certainly 575 linked to the middle Bronze Age climate event (so-called Löbben in the Alpine area), which implied 576 cooler and wetter conditions between 3.5 and 3.2-3.1 kyr. cal BP in western Europe (Berger et al., 577 2007; Burga et al., 2001; Deák et al., 2017b; Magny et al., 2009). These two high-energy hydro578 sedimentary episodes are therefore the first serious sedimentary evidence of 4.2 and 3.5 kyr. BP 579 climate events in Limagne plain, although they have been recently documented in mountainous 
580 highlands of the Massif Central (Chassiot et al., 2018). The intermediary low-energy phase coincided

581 with a more stable hydro-climatic period, detected in alpine lakes and glacial basins (regression 582 phases) and in the Rhone valley by a general trend to pedogenesis and river entrenchment (Berger et 583 al., 2007; Joerin et al., 2006; Magny, 2004; Magny et al., 2009).

584 NAR3 data show that marginal areas of the basin were also affected by these phases of degraded 585 hydro-sedimentary dynamics: malacological assemblages indicated a progression of marshland 586 environments and biological activity decreased (fall of OM). Data from both cores clearly indicated 587 wetter conditions and absence of significant anthropogenic impact on lowlands soils and vegetation. 588 This situation contrasted with dryer areas of other sectors of Limagne plain where human impact was 589 presumably more significant (Miras et al., 2018). Archaeological findings nevertheless remain rare in 590 Limagne for this period, excepting between 3950 and 3550 BP, when the Limagne was densely 591 occupied by substantial settlements (Couderc, 2019). Taken together, these data suggest a certain 592 degree of adaptation of Early and Middle Bronze age societies to hydro-climatic fluctuations in 593 lowlands. Nevertheless, the potential interaction of these hydro-sedimentary phenomena with 594 anthropogenic impacts on soils during Late Neolithic and Early Bronze Age cannot be clearly assessed 595 from the analyzed pedo-sedimentary record.

596

$597 \quad 4.3$ Late Bronze Age and Early Iron Age

598

599 The global trend during the Late Bronze Age and first century of the Iron Age (3250-2600 cal 600 BP, phases N2.5A-B and N3.2B in Fig. 10, see Fig. 11) was towards a decrease of hydro-sedimentary activity in the whole basin. Drainage seems slightly degraded with presence of stagnant water especially in central lower areas of the depression (weak OM content, malacological assemblages rich 
604 and fluctuating watertable. This phase of degraded drainage could partly correspond to the start of a 605 major climate deterioration occurring at c. 2800 BP in western Europe, with cooler and wetter 606 conditions prevailing until c. 2400 BP (Berger et al., 2007; Fletcher, Debret and Sanchez-Goñi, 2013; 607 Holzhauser et al., 2005; Magny et al., 2009; Van Geel and Magny, 2002; Walsh et al., 2019).

608 Despite these unfavorable hydrological conditions in the basin itself, a more open landscape (as 609 indicated by malacology) points to clearly localized anthropogenic impact, likely connected to the use 610 of fire (abundant micro- and macrocharcoal, Fig. 10), maybe for pastoral use. Additionally, the rise of 611 fine volcanic sediment input (rise of Sediment Accumulation Rate -SAR- and Fe/Ca ratio, lower D50) 612 suggests increased anthropogenic impacts affecting soils of the catchment slopes. This is consistent 613 with archaeological data, which show development of agglomerations on the hilltops of Limagne at 614 the end of the Bronze Age (3100-2750 cal BP), whereas slopes and lowlands seem devoted to 615 agricultural and pastoral activities (Couderc, 2019).

During later phases of the first Iron Age (2600-2375 cal BP, phase N2.6A and beginning of 617 N3.3A in Fig. 10, see also Fig. 11) the situation was radically different: abrupt pedo-hydrological 618 changes affected the basin since c. 2600 cal BP. The environment became much drier and landscape 619 opened further as clearly indicated by malacological assemblages. Soils became cumulic and 620 isohumic in the depression with residual hydromorphic features due to seasonal short flooding 621 episodes as indicated by micromorphology and malacological assemblages. Moreover, they present 622 micromorphological (microstructure, porosity, organic matter, pedofeatures, etc.), sedimentological 623 (OM rate increments in both cores) and malacological (reduced biodiversity) evidences of major 624 anthropogenic-induced modifications and impacts, consistent with local agricultural use starting 625 from c. 2600 cal BP. Additionally, SAR rises strongly especially in lower areas of the basin with 626 predominance of fine volcanic sediment, suggesting that erosion of soils of the catchment had similar 627 intensity to the previous period, but became more generalized (grain-size and Fe/Ca ratio, Fig. 10). 
628 Taken together, these data clearly indicate a strong spatial expansion of agricultural impacts on soils 629 in this catchment of southern Limagne, affecting for the first time the wet lowlands c. 2600 cal BP. It 630 is noteworthy that similar phenomena are noted in the Rhone valley or in Rhineland also at the 631 beginning of the Iron Age (Houben et al., 2012; Notebaert and Berger, 2014). This expansion 632 necessarily implied a new technical capacity to drain and cultivate wetlands at least two centuries 633 before than usually admitted in Limagne (Trément et al., 2007a; Trément, 2011). This early drainage 634 capacity certainly represented a break in the socio-environmental interaction in the Limagne 635 lowlands hitherto unsuspected, and a major step towards environmental systems anthropization. 636 Even if needing confirmation through additional investigations, this precocity is not out of place since 637 drainage capacity was likely developed from the beginning of the Iron Age in central France, allowing 638 hydraulic developments and small settlements on former wetlands (Bernigaud et al., 2014; Milcent 639 and Mennessier-Jouannet, 2007; Riquier et al., 2015; Walsh et al., 2019). Remarkably, the emergence 640 of a proto-urban settlement including hundreds of storage pits in the neighboring Puy de Corent 641 takes place only few decades (from c. 2550 cal. BP) after the beginning of impacts on soils noted at la 642 Narse wet lowlands (Mayoral et al., 2018b; Milcent et al., 2014), and is maybe related to locally 643 increased agricultural production. 
645

3

4

6

7

9

10

11

12

1

14

15

16

17

18

19

20

21

2

23

24

25

26

27

28

29

30

31

32

33

34

35

36

37

3

39

40

42

43

Figure 10. Multi-proxy synthetic diagram for NAR2 (A) and NAR3 (B) cores (MS: Magnetic Susceptibility. D50: median grain-size. SAR: Sediment Accumulation Rate. OM: Organic Matter content). 
646

647

648

649

650

651

652

653

654

655

656

657

658

659

660

661

662

663

664

665

666

667

668

669

\subsection{Late Iron Age}

All proxies suggest that environmental dynamics at La Narse de la Sauvetat during the Late Iron Age (2375-1980 cal BP, phases 2.6B to E and N3.3A and B in Fig. 10, see also Fig. 11) were broadly similar to the previous centuries, with soil cultivation, use of fire and probable drainage works. Increased fine sediment inputs into the basin, together with micromorphological and geochemical evidence of intensified fires and soil erosion, indicate that agricultural impact on soils of the catchment became gradually more generalized and reached a maximum between 2250 and 2150 cal BP.

From 2250 cal BP onwards and until the end of the Iron Age, micromorphological and malacological data suggest that despite generally drier soils across the basin, hydrological conditions were slightly unstable. Short floods were more frequent, even if limited to the lower part of the basin, particularly between 2150 and 2050 cal BP. The reduced energy of sedimentary inputs and a decrease in volcanic fraction indicated by sedimentological and geochemical proxies, together with a reduced accumulation rate suggest a gradually reduced connectivity with catchment slopes.

Local socio-environmental dynamics at la Narse de la Sauvetat are roughly consistent with increased anthropogenic impacts noted in previous works on Limagne. For the last centuries of the Iron Age, human impact in environmental systems became strong and generalized (Ballut, 2000; Ballut and Guichard, 2005; Trément et al., 2007a; Trément, 2011), while climatic conditions were more favorable to agricultural activities during the Roman Warm Period (Magny, 2004 ; McCormick et al., 2012). Reduction of sedimentary inputs into the basin could be connected with the emergence and development of new agricultural practices in Limagne, such as improved drainage networks or terraced fields on the slopes (Ballut and Guichard, 2005; Trément et al., 2007a; Trément, 2011). These anthropogenic modifications of hydro-sedimentary systems may have significantly contributed to contain soil erosion and hydro-sedimentary degradation. 
670

671

673

674

675

676

677

678

679

680

681

682

683

684

685

686

687

688

689

690

691

692

693

694

\subsection{Antiquity}

The Roman epoch (1980 to 1474 cal. BP, phases N2.6E to N2.7B and N.3.3B to N3.4B, Fig. 10, see also

Fig. 11) appears to be a very strong anthropogenic impact period in the basin. Soil micromorphology, relatively high $\mathrm{OM}$ content and malacology indicate more intensive agriculture and an improved drainage. Several $\mathrm{Pb} / \mathrm{Rb}$ peaks in both cores (Fig. 10), not correlated with detrital inputs, indicate local metallurgical activity from c. 1950 cal BP to c. 1600 cal BP. The maintained decrease of SAR in the basin and the soil profile stability during the Early Roman Empire (incipient illuviation, Fig. 6) can be interpreted as a strong control of hydro-sedimentary inputs. A pronounced deterioration and anthropogenic erosion of volcanic soils of the catchment can nevertheless be deduced from the increased number of coarse volcanic particles and the geochemical composition of fine fraction (high values of $\mathrm{Fe} / \mathrm{Ca}$ since c. $1800 \mathrm{cal} \mathrm{BP}$ ). Impacts on soils and especially on hydro-sedimentary system became more evident after $1700 \mathrm{cal} \mathrm{BP}$, with micromorphological data suggesting more fluctuant hydrological conditions and high detrital inputs from volcanic slopes (Fe/Ca, Fig.10).

These environmental data are consistent with local archaeological evidence, with several Roman settlements (including a very extended villa) indicating increased human impacts in La Narse de la Sauvetat basin (Simon et al., 2017), similar to the neighboring Sarliève palaeolake (Fourmont, 2006 ; Trément et al., 2007a; Trément, 2011; Vernet, 2001; Vernet et al., 2005). At a regional level, human impact on natural systems also became very strong during the Roman period (Ballut and Guichard, 2005; Berger, 2015; Notebaert and Berger, 2014). Hydro-sedimentary and soil degradation after 1700 cal BP could be linked to a short phase of colder and drier climate between 1750 and 1650 cal BP, which was followed by relatively unstable hydro-climatic conditions (Buntgen et al., 2011; Holzhauser et al., 2005). However, resilience of Late Roman Empire agrarian structures probably allowed settlers to contain sedimentary inputs into the basin, or efficiently evacuate them through a drainage network. 
Figure 11. Comparison of palaeoenvironmental evidence in la Narse de la Sauvetat between 5000 and 1200 cal BP (derived from core NAR2, this study) with regional archaeological data in Limagne plain and climatic changes in Western Europe.

NAR2 environmental phases are from Fig. 10A. Representations of local hydrological conditions, soil erosion in the catchment and detrital inputs are qualitative (relative level or thickness according to process intensity) and based on data from Fig. 10. High-energy hydro-sedimentary episodes related to 4.2 and $3.5 \mathrm{kyr}$. cal BP climatic events are indicated (note a chronological offset of 150-200 yr. of the first episode, see the text for details). Local vegetation cover (qualitative) is represented by the proportion of shade-demanding malacological species vs. other terrestrial malacological species. Anthropic activities (landscape opening, use of fire, pastoral activity, agriculture and metallurgical activity) are represented by symbols. RWP: Roman Warm Period. LALIA: Late Antiquity Little Ice Age. Settlement density in Limagne is based on (1) Ballut and Argant, 2004; Couderc, 2019; Daugas and Raynal, 1989; Milcent and Mennessier-Jouannet, 2007; Raynal et al., 2003; Trément et al., 2007; Trément, 2011. Phases of climatic deterioration in Western Europe are based on (2) Berger et al., 2007; Brisset et al., 2013; Buntgen et al., 2011; Carozza et al., 2015; Fletcher, Debret and Goñi, 2013; Holzhauser et al., 2005; Joerin et al., 2006; Magny, 2004; Magny et al., 2009; McCormick et al., 2012; Van Geel and Magny, 2002; Walker et al., 2019; Walsh et al., 2019.

\subsection{Late Antiquity and early Middle Ages}

The transition from Antiquity to the early Middle Ages (1500 to $1200 \mathrm{cal}$ BP, N2.8A to C and

N3.4A to N3.5, Fig. 10, see also Fig. 11) is characterized by a major palaeoenvironmental change at la

Narse de la Sauvetat, starting from c. 1500 cal BP with sudden deposition of a black, organic and charcoal-rich layer. Based on geochemical, micromorphological and malacological data, this deposit has been interpreted as a marsh resulting from flooding of the lower areas of the depression whereas open landscape was maintained in drier peripheral areas. Detrital inputs were reduced (lower MS, low SAR), but remained relatively rich in volcanic fraction (Fe/Ca).

This palustrine phase was very similar to the well-known "dark layer" of the Sarliève palaeolake a few kilometers north, dated approximately between 1850 and 1750 cal BP. That layer has been interpreted as the result of introduction in hillslopes of the catchment of new pastoral practices involving fire combined with a late-Antiquity hydro-climatic degradation (Buntgen et al., 2011; Trément et al., 2007a; Trément, 2011; Vernet, 2001; Vernet et al., 2005). However, the dark layer observed at la Sauvetat has a 300-year chronological offset respect the Sarliève one: this strongly suggests that this major change had little to do with climate excursions, but was more likely due to modifications of anthropogenic activities on the catchment, implying sudden deterioration of drainage networks or even outlet modifications. 
728 Moreover, the strong hydro-sedimentary "crisis" sometimes noted in Limagne from 1550 or 1450 cal 729 BP in previous works and often attributed to socio-climatic drivers (Ballut, 2001; Ballut and Guichard, 730 2005; Trément et al., 2007a, 2007b; Vernet, 2013), is remarkably absent here. This suggests that, at 731 least locally, late Antiquity landscape changes, due to modifications in anthropic activities and in land 732 management, were gradual and controlled instead of abrupt and catastrophic. Spatial 733 reorganizations and differential land use can explain these environmental variations at the micro734 regional scale. Similar dynamics of land-use changes in wet lowlands during Late Antiquity or early 735 Middle Ages have been identified by palaeoenvironmental research in SE France, and are likely 736 connected with hydraulic systems abandonment (Berger, 1995; Durand \& Leveau, 2004), but the 737 question remains nevertheless obscure in Limagne and would require further investigations. The picture between 1400 and 1300 cal BP is less ambiguous as water level rose in the basin: lower areas became clearly aquatic (with in situ travertine formation) and palustrine environments prograded to the margins of the depression. This marked drainage deterioration is also noted in other Limagne marshy areas (Trément, 2011; Vernet et al, 2005; Vernet, 2013), and was followed by slightly dryer conditions after 1300 cal BP. Strong hydro-climatic phenomena are locally noted in Limagne by scarce but reliable historical sources mentioning increased floods and seismicity (Daugas and Tixier, 1975; Vernet, 2011; Vernet, 2013). These dynamics are in accord with hydro-climatic degradation between 1450 and 1250 cal BP, which is well documented at western European scale 746 (Arnaud et al., 2012; Berger and Brochier, 2006; Buntgen et al., 2011; Magny, 2004; McCormick et al., 747 2012). The influence of new forms of human management on this wetland remains nevertheless 748 difficult to assess based only on these palaeoenvironmental insights, and further research is 749 necessary to better understand socio-environmental interaction driving the early medieval landscape 750 changes at la Narse de la Sauvetat.

\section{5-Conclusion}


753 This work used multi-proxy geoarchaeological and palaeoenvironmental analysis to reconstruct 754 landscape evolution and human-environment interactions at La Narse de la Sauvetat. 755 Micromorphological, geochemical, sedimentological and malacological data supported by a robust 756 chronological framework allowed for the first time in Limagne lowlands a precise discussion 757 concerning the weight of anthropogenic and climatic drivers on pedo-hydro-sedimentary processes 758 and landscape evolution of the basin from Late Neolithic to the early Middle Ages.

759 The Late Neolithic was poorly documented in the pedo-sedimentary analyzed records, but 760 nevertheless anthropogenic modifications of vegetation cover could be discerned. Until the Middle 761 Bronze Age, hydro-sedimentary dynamics in the depression were strong and clearly climate-driven by the 4.2 and $3.5 \mathrm{kyr}$ cal BP climate events, characterized for the first time in Limagne lowlands. The 763 first clear evidences of incipient anthropogenic impact in soils of the basin and the catchment 764 appeared in the Late Bronze Age, under slightly better hydro-climatic conditions.

765 However the decisive phase in human impact affecting soil erosion, hydro-sedimentary system and 766 wet areas of the catchment occurred at the opening of the Iron Age. Despite probably less favorable climatic conditions during some centuries after $2750 \mathrm{cal}$ BP, agricultural impacts on soils of the basin became evident c. 2600 cal BP and were probably accompanied by drainage works, as soil erosion in the catchment rose.

Hallstatt societies seemed therefore to have acquired a first degree of emancipation from hydro-

771 climatic constraints affecting these wet lowlands, crossing a major threshold in socio-environmental 772 interaction in southern Limagne. This precocious forcing of soils and hydro-sedimentary system 773 occurred considerably earlier than the Late Iron Age turning point (2250-2050 cal BP) usually 774 accepted in Limagne. These dynamics were reinforced during La Tène and Roman periods, and 775 impact on soils and hydro-sedimentary system expanded and deepened. However after reaching a peak c. 2200 cal BP the hydro-sedimentary consequences of rising anthropogenic impact appeared to decrease. This is probably due to improved land management and agricultural techniques including 
778 hydraulics, allowing more efficient management and containment of erosion processes. Despite 779 rather favorable climatic conditions, a disruption in hydro-sedimentary system became gradually 780 discernible throughout the Roman period and especially during the Late Roman Empire. This signal 781 could be due to more unstable climatic conditions contributing to upset an anthropogenic 782 environmental system with centuries of cumulative impacts.

783 Sudden drainage degradation and the advent of palustrine conditions in the basin from 1500 cal BP 784 were remarkably asynchronous with other similar local dynamics. They were probably more the 785 result of modifications of land management rather than of hydro-climatic degradation that occurred 786 anyway a century later. These results go against the idea of a dramatic "collapse" of late Antiquity 787 socio-environmental systems in southern Limagne, drawing a more complex picture. They rather 788 indicate that, at least locally, their relative resilience could have allowed a fast but nevertheless 789 gradual transition to a new equilibrium in the early Middle Ages, characterized by abandonment of 790 drainage networks and occupation of lowlands by lacustro-palustrine environments under oscillating 791 climatic conditions.

792 Ultimately, this work confirmed that multi-proxy, high resolution analysis is the most fruitful 793 approach to develop in Limagne lowlands, where the interpretation of socio-environmental 794 interaction based on palaeoenvironmental record of soils and wetlands had long been limited. The 795 obtained results, partly consistent with previous knowledge, raised specific questions due to 796 increased chronological and analytical resolution, which would be regionally addressed by further 797 multi-disciplinary research.

\section{6-Acknowledgements}

799 This work was carried out as a part of the AYPONA project (Dir. Y. Miras and F. Vautier) funded by the 800 Conseil Régional d'Auvergne (Fr.). Analyses were funded by University Lyon 2 (Projet BQR - University 801 Lyon 2, dir. M. Poux and J-F. Berger). Coring was performed with financial support of the Zone Atelier 
802 Loire. The authors want to acknowledge the landowners M. Favy and M. De Quatrebarbes who

803 allowed access to their fields. We are also grateful to a number of persons who contributed to this 804 work with their support in the field, with laboratory assistance, or with valuable scientific discussions: 805 Aude Beauger, Erwan Roussel, Alexandre Garreau, François-Xavier Simon, Alexandre Poiraud, Laura 806 Benedito, Pierre Boivin, Franck Vautier, Bertrand Dousteyssier, Florian Couderc, Olivier Voldoire, Paul 807 Ledger, Manon Cabanis, Fayçal Soufi and Adrien Barra. Lastly, we express sincere thanks to the 808 reviewers for their critical reading of the manuscript and constructive remarks.

\section{7-Conflicts of interest}

The authors declare no conflict of interest. The founding sponsors had no role in the design of the study; in the collection, analyses, or interpretation of data; in the writing of the manuscript, and in the decision to publish the results.

\section{8-References}

Adderley WP, Wilson CA, Simpson IA, et al. (2010) Anthropogenic Features. In: Interpretation of

Arnaud F, Serralongue J, Winiarski T, et al. (2006) Pollution au plomb dans la Savoie antique (II-IIle s. apr. J.-C.) en relation avec une installation métallurgique de la cité de Vienne. Comptes Rendus Geoscience 338(4): 244-252. DOI: 10.1016/j.crte.2005.11.008.

Arnaud F, Révillon S, Debret M, et al. (2012) Lake Bourget regional erosion patterns reconstruction reveals Holocene NW European Alps soil evolution and paleohydrology. Quaternary Science 
Reviews 51. Elsevier Ltd: 81-92. DOI: 10.1016/j.quascirev.2012.07.025.

826

827

828

829

830

831

832

833

834

835

836

837

838

839

840

841

842

843

844

845

846

847

Bajard M, Sabatier P, David F, et al. (2015) Erosion record in Lake La Thuile sediments (Prealps, France): Evidence of montane landscape dynamics throughout the Holocene. The Holocene 26(3): 350-364. DOI: 10.1177/0959683615609750.

Ballut and Argant J (2004) Les dynamiques géomorphologiques et environnementales dans la Limagne humide de Clermont-Ferrand du Néolithique au début de l'Age du Fer. In: $5 e$ Rencontres méridionales de Préhistoire récente Auvergne et Midi, Clermont-Ferrand, 2004.

Ballut C (2000) Evolution environnementale de la Limagne de Clermont-Ferrand au cours de la seconde moitié de l'holocène (Massif central français). Université de Limoges. Available at: http://www.theses.fr/2000LIMO2004.

Ballut C (2001) Evolution géomorphologique et hydrologique dans les marais de Limagne au cours de la seconde moitié de I' Holocène (Massif central , France ) / Geomorphological and hydrological evolution in the Limagne swamps during the second part of the Holocene. Quaternaire 12(1-2): 43-51.

Ballut C and Guichard V (2005) Anthropisation et milieu humide en Limagne de Clermont-Ferrand depuis le Neolithique. In: Occupation et gestion des plaines alluviales dans le Nord de la France de l'âge du Fer à l'époque gallo-romaine (ed. C Petit), Besançon, 2005, pp. 135-141. Presses Universitaires de Franche-Comté.

Berger, Brochier JL, Vital J, et al. (2007) Nouveau regard sur La dynamique des paysages et l'occupation humaine à L'Âge du Bronze en moyenne vallée du Rhône. In: Environnements et cultures à l'Age du bronze en Europe occidentale (eds H Richard, C Mordant, and M Magny), Paris, 2007, p. 399. Editions du CTHS.

Berger J-F (1995) Facteurs anthropiques et naturels de l'évolution des paysages romains et 
848

849

850

851

852

853

854

855

856

857

858

859

860

861

862

863

864

865

866

867

868

869

870

protomédiévaux du Bassin valdainais (Drôme). L’homme et la dégradation de l'environnement. XVèmes Rencontres Internationales d'Archéologie et d'Histoire d'Antibes. Editions APDCA, Juanles-Pins: 79-114.

Berger J-F and Brochier J-L (2006) Paysages et climats en moyenne vallée du Rhône : apports de la géoarchéologie. In: Habitats, Nécropoles et Paysages Dans La Moyenne et Basse Vallée Du Rhône (VIle-XVe s.). Contribution Des Travaux Du TGV-Méditerranée à l'étude Des Sociétés Rurales Médièvales. Documents d’Archéologie Française, pp. 163-208.

Berger J-F, Shennan S and Woodbridge J (2019) Holocene land cover and population dynamics in Southern France. The Holocene: 31-34. DOI: 10.1177/0959683619826698.

Berger J (2015) Approche socio-environnementale du Néolithique à l'Anthropocène : quelques études intégrées de la Vallée du Rhône aux milieux Nord Méditerranéens. Habilitation à Diriger les Recherches. Université de Lyon 2.

Berger JF, Delhon C, Magnin F, et al. (2016) A fluvial record of the mid-Holocene rapid climatic changes in the middle Rhone valley (Espeluche-Lalo, France) and of their impact on Late Mesolithic and Early Neolithic societies. Quaternary Science Reviews 136: 66-84. DOI: 10.1016/j.quascirev.2015.11.019.

Bernigaud N, Berger J-F, Bouby L, et al. (2014) Ancient canals in the valley of Bourgoin-La Verpillière (France, Isère): morphological and geoarchaeological studies of irrigation systems from the Iron Age to the Early Middle Ages (8th century bc-6th century ad). Water History 6(1): 73-93. DOI: 10.1007/s12685-013-0096-9.

Birks HH and Birks HJB (2006) Multi-proxy studies in palaeolimnology. Vegetation History and Archaeobotany 15(4). Springer-Verlag: 235-251. DOI: 10.1007/s00334-006-0066-6.

Blaauw M (2010) Methods and code for 'classical' age-modelling of radiocarbon sequences. 
Quaternary Geochronology 5(5). Elsevier: 512-518. DOI: 10.1016/J.QUAGEO.2010.01.002.

872 Blott SJ and Pye K (2001) Gradistat: A Grain Size Distribution and Statistics Package for the Analysis of 873 Unconcolidated Sediments. Earth Surface Processes and Landforms 26: 1237-1248. DOI: $874 \quad 10.1002 /$ esp.261.

875 Bornand M, Callot G, Favrot J-C, et al. (1968) Les sols du Val d'Allier, notice explicative de la carte 876 pédologique au 1/100.000ème. Montpellier: INRA, Service d'étude des sols.

877 Bouiller R (1979) Minute de la carte Géologique de la France à 1:50000, feuille 717 (Veyre-Monton). $878 \quad$ BRGM.

879 Bravard J-P and Peiry J-L (1999) The CM pattern as a tool for the classification of alluvial suites and 880 floodplains along the river continuum. Floodplains: Interdisciplinary Approaches 163(1969): 881 259-268. DOI: 10.1144/GSL.SP.1999.163.01.20.

BRGM (1973) Carte Geologique 1/50.000 No693 (Clermont-Ferrand). BRGM (ed.). Orléans: BRGM.

Brisset E, Miramont C, Guiter F, et al. (2013) Non-reversible geosystem destabilisation at 4200 cal. 884 885 886 887 888 BP: Sedimentological, geochemical and botanical markers of soil erosion recorded in a Mediterranean alpine lake. Holocene 23(12): 1863-1874. DOI: 10.1177/0959683613508158.

Brown A, Toms P, Carey C, et al. (2013) Geomorphology of the Anthropocene: Time-transgressive discontinuities of human-induced alluviation. Anthropocene 1. Elsevier B.V.: 3-13. DOI: 10.1016/j.ancene.2013.06.002.

Brown AG, Tooth S, Bullard JE, et al. (2016) The geomorphology of the Anthropocene: emergence, status and implications. Earth Surface Processes and Landforms 42(1): 71-90. DOI: 10.1002/esp.3943. 578-582. 
894 Burga CA, Perret R and Zoller H (2001) Swiss localities of early recognized Holocene climate

895 oscillations: Characterization and significance. Vierteljahrsschrift der Naturforschenden

$896 \quad$ Gesellschaft in Zuerich 146(2-3): 65-74.

897 Carozza L, Berger J, Burens A, et al. (2015) Society and environment in Southern France from the 3rd

898 millenium BC to the beginning of the $2 \mathrm{~d}$ millenium BC a tipping point? In: 2200 BC - Ein

899 Klimasturz Als Ursache Für Den Zerfall Der Alten Welt ? 2200 BC-A Climatic Breakdown as a

$900 \quad$ Cause for the Collapse of the Old World ?, pp. 833-844.

901 Chassiot L, Miras Y, Chapron E, et al. (2018) A 7000-year environmental history and soil erosion

902 record inferred from the deep sediments of Lake Pavin (Massif Central, France).

903 Palaeogeography, Palaeoclimatology, Palaeoecology 497(February). Elsevier: 218-233. DOI:

$904 \quad$ 10.1016/j.palaeo.2018.02.024.

905 Couderc F (2019) La basse Auvergne (Puy-de-Dôme, sud Allier) : un espace privilégié pour l'étude des

906 territoires et des paysages de l'âge du Bronze. In: Colloque international anniversaire de I'

$907 \quad$ APRAB, Bayeux, 2019, pp. 94-97. APRAB.

908 Courty M-A, Goldberg P and MacPhail RI (1989) Soils and Micromorphology in Archaeology.

909 Cambridge manuals in archaeology. DOI: 10.1016/B978-0-444-53156-8.00031-3.

910 Croudace IW and Rothwell RG (2015) Micro-XRF Studies of Sediment Cores. New York London:

911 Springer. DOI: 10.1007/978-1-4020-5725-0_3.

912 Crutzen PJ and Stoermer EF (2000) The 'Anthropocene'. Global Change Newsletter 41(41): 17-18.

913 Available at:

914 http://www.igbp.net/publications/globalchangemagazine/globalchangemagazine/globalchange

$915 \quad$ newslettersno4159.5.5831d9ad13275d51c098000309.html.

916 Daugas and Raynal JP (1989) Quelques étapes du peuplement du Massif central francais dans leur 
contexte paléoclimatique et paléogeographique Some stages of prehistoric settlement in Massif Central. Cahiers du Quaternaire 13: 67-95.

Daugas J-P and Tixier L (1977) Variations paleoclimatiques de la Limagne d'Auvergne. Approche 920 écologique de l'Homme Fossile, supplément au Bulletin de l'AFEQ 47: 203-235.

Daugas J and Tixier L (1975) Variations Paléoclimatiques de la Limagne d'Auvergne. Bulletin de I'Association française pour l'étude du Quaternaire 47: 203-235.

Deák J, Magny M and Wüthrich S (2017) Late Neolithic to Middle Bronze Age (around 4900-3100 cal. BP) lake-level fluctuations at Lake Neuchâtel (Switzerland) as reflected by the sediment sequence of the site of Colombier/Les Plantées de Rive: Palaeoclimatic and archaeological implications. Holocene 28(1): 3-18. DOI: 10.1177/0959683617714598.

Deák J, Gebhardt A, Lewis H, et al. (2017) Soils Disturbed by Vegetation Clearance and Tillage. In: Archaeological Soil and Sediment Micromorphology. Chichester, UK: John Wiley \& Sons, Ltd, pp. 231-264. DOI: 10.1002/9781118941065.ch28.

Dearing J (1999) Magnetic susceptibility. Environmental magnetism: A practical guide 6. Quaternary Research Association, London, Technical Guide: 35-62.

Delvigne J (1998) Atlas of Micromorphology of Mineral Alteration and Weathering. The canadian Mineralogist. Available at: http://petrology.oxfordjournals.org/content/41/3/475.2.short.

Demény A, Kern Z, Czuppon G, et al. (2019) Middle Bronze Age humidity and temperature variations, and societal changes in East-Central Europe. Quaternary International 504(November): 80-95. DOI: 10.1016/j.quaint.2017.11.023.

Dotterweich M (2013) The history of human-induced soil erosion: Geomorphic legacies, early descriptions and research, and the development of soil conservation-A global synopsis. Geomorphology 201. Elsevier B.V.: 1-34. DOI: 10.1016/j.geomorph.2013.07.021. 
940 Dreibrodt S, Lubos C, Terhorst B, et al. (2010) Historical soil erosion by water in Germany: Scales and 941 archives, chronology, research perspectives. Quaternary International 222(1-2). Elsevier Ltd: 80-95. DOI: 10.1016/j.quaint.2009.06.014.

\section{Durand A and Leveau P (2004) FARMING IN MEDITERRANEAN FRANCE AND RURAL SETTLEMENT IN} THE LATE ROMAN AND EARLY MEDIEVAL PERIODS : THE CONTRIBUTION FROM ARCHAEOLOGY AND ENVIRONMENTAL SCIENCES IN THE LAST TWENTY YEARS. In: Barceló M and Sigaut F (eds) The Making of Feudal Agricultures. BRILL, pp. 177-253.

Durand N, Monger HC and Canti MG (2010) Calcium Carbonate Features. In: Interpretation of Micromorphological Features of Soils and Regoliths. Elsevier, pp. 149-194. DOI: 10.1016/B9780-444-53156-8.00009-X.

Ellis EC, Kaplan JO, Fuller DQ, et al. (2013) Used planet: A global history. Proceedings of the National Academy of Sciences 110(20): 7978-7985. DOI: 10.1073/pnas.1217241110.

Ellis EC, Magliocca NR, Stevens CJ, et al. (2017) Evolving the Anthropocene: linking multi-level selection with long-term social-ecological change. Sustainability Science 13(1). Springer Japan: 119-128. DOI: 10.1007/s11625-017-0513-6.

Evans JG (1972) Land Snails in Archaeology; with Special Reference to the British Isles. Seminar Press. Available at: https://books.google.fr/books/about/Land_Snails_in_Archaeology.html?id=Yg_AAAAIAAJ\&redir_esc=y (accessed 29 January 2019).

Fedoroff N and Courty M-A (2002) Paléosols et sols reliques. Miskovsky JC Géologie de la préhistoire, Association pour l'étude de l'environnement géologique de la préhistoire, Paris: 277-316.

Fedoroff N, Courty M-A and Guo Z (2010) Palaeosoils and Relict Soils. In: Interpretation of Micromorphological Features of Soils and Regoliths. Elsevier, pp. 623-662. DOI: 10.1016/B9780-444-53156-8.00027-1. 
963 Fernández-Götz M (2018) Urbanization in Iron Age Europe: Trajectories, Patterns, and Social

964 Dynamics. Journal of Archaeological Research 26(2): 117-162. DOI: 10.1007/s10814-017-9107-

9651.

966 Fletcher WJ, Debret M and Sanchez-Goñi M-F (2013) Mid-Holocene emergence of a low-frequency 967 millennial oscillation in western Mediterranean climate: Impications for past dynamics of the 968 North Atlantic atmosphere westerlies. The Holocene: 1-14. DOI: 10.1177/0959683612460783.

969 Fletcher WJ, Debret M and Goñi MFS (2013) Mid-Holocene emergence of a low-frequency millennial 970

Gebhardt A, Occhietti S and Fechner K (2014) Grandes phases de pédogenèse, d'érosion et oscillation in western Mediterranean climate: Implications for past dynamics of the North Atlantic atmospheric westerlies. The Holocene 23(2). SAGE PublicationsSage UK: London, England: 153-166. DOI: 10.1177/0959683612460783.

Fourmont A (2006) Quantification de l'érosion et de la sédimentation dans le bassin de Sarliève (Massif Central, France) au tardiglaciaire et à l'Holocène : Impact des facteurs naturels et anthropiques. Université François Rabelais-Tours. Available at: http://www.theses.fr/2005TOUR4033.

Fourmont A, Macaire JJ and Bréhéret JG (2009) Contrasted Late Glacial and Holocene hydrology of Sarliève paleolake (France) from sediment geometry and detrital versus biochemical composition. Journal of Paleolimnology 41(3): 471-490. DOI: 10.1007/s10933-008-9238-y.

Freytet P and Verrecchia EP (1998) Freshwater organisms that build stromatolites: a synopsis of biocrystallization by prokaryotic and eukaryotic algae. Sedimentology 45(3): 535-563. DOI: d'anthropisation des sols au cours de la seconde moitié de l'Holocène en Lorraine. ArchéoSciences 38: 7-29. 
986 Gerasimova M and Lebedeva-Verba M (2010) Topsoils - Mollic, Takyric and Yermic Horizons. In:

987

988

989

990

991

992

993

994

995

996

997

998

999

1000

1001

1002

1003

1004

1005

1006

1007

1008 Interpretation of Micromorphological Features of Soils and Regoliths. Elsevier, pp. 351-368. DOI: 10.1016/B978-0-444-53156-8.00016-7.

Goudie A and Viles HA (2016) Geomorphology in the Anthropocene. Cambridge: Cambridge University Press.

Greffier G, Restituito J and Héraud H (1980) Aspects géomorphologiques et stabilité des versants au sud de Clermont-Ferrand. Bulletin de liaison du Laboratoire des Ponts et Chaussées 107: 17-26.

Guilloré P (1980) Méthode de Fabrication Mécanique et En Série Des Lames Minces. 2ème éditi. Paris, Grignon: CNRS et INA-PG.

Heiri O, Lotter AF and Lemcke G (2001) Loss on ignition as a method for estimating organic and carbonate content in sediments: reproducibility and comparability of results. Journal of Paleolimnology 25(1). Kluwer Academic Publishers: 101-110. DOI: 10.1023/A:1008119611481.

Holzhauser H, Magny M and Zumbühl HJ (2005) Glacier and lake-level variations in west-central Europe over the last 3500 years. Holocene 15(6): 789-801. DOI: 10.1191/0959683605hl853ra.

Horsák M, Juřičková L and Picka J (2013) Měkkýši České a Slovenské Republiky = Molluscs of the Czech and Slovak Republics. Available at: https://www.nhbs.com/molluscs-of-the-czech-and-slovakrepublics-mkkyi-eske-a-slovenske-republiky-book (accessed 29 January 2019).

Houben P, Schmidt M, Mauz B, et al. (2012) Asynchronous Holocene colluvial and alluvial aggradation: A matter of hydrosedimentary connectivity. The Holocene 23(4): 544-555. DOI: $10.1177 / 0959683612463105$.

Jeffery S, Gardi C, Jones A, et al. (2010) European Atlas of Soil Biodiversity. Chart. English Ed. Luxembourg: JRC-European Comission. DOI: 10.1016/S0016-7061(99)00028-2.

Joerin UE, Stocker TF and Schlüchter C (2006) Multicentury glacier fluctuations in the Swiss Alps 

during the Holocene. The Holocene 16(5): 697-704. DOI: 10.1191/0959683606hl964rp.

Joly D, Brossard T, Cardot H, et al. (2010) Les types de climats en France, une construction spatiale Types of climates on continental France, a spatial construction. Cybergéo : European Journal of Geography (501): 1-23. DOI: 10.4000/cybergeo.23155.

Jongerius A (1970) Some morphological aspects of regrouping phenomena in dutch soils. Geoderma 4.

Kerney MP, Cameron RAD and Bertrand A (2006) Guide Des Escargots et Limaces d'Europe. Delachaux et Niestlé.

Kooistra MJ and Pulleman MM (2010) Features Related to Faunal Activity. In: Interpretation of Micromorphological Features of Soils and Regoliths. Elsevier, pp. 397-418. DOI: 10.1016/B9780-444-53156-8.00018-0.

Kovda I and Mermut AR (2010) Vertic Features. In: Interpretation of Micromorphological Features of Soils and Regoliths. Elsevier, pp. 109-127. DOI: 10.1016/B978-0-444-53156-8.00007-6.

Kühn P, Aguilar J and Miedema R (2010) Textural Pedofeatures and Related Horizons. In: Interpretation of Micromorphological Features of Soils and Regoliths. Elsevier, pp. 217-250. DOI: 10.1016/B978-0-444-53156-8.00011-8.

Lang A (2003) Phases of soil erosion-derived colluviation in the loess hills of South Germany. Catena 51(3-4): 209-221. DOI: 10.1016/S0341-8162(02)00166-2.

Legrand P, Bartoli F and Curt T (2007) Spécificités des sols volcaniques du Massif Central: bénéfices et contraintes pour la gestion forestière. Revue Forestière Française 59(2).

Lindbo DL, Stolt MH and Vepraskas MJ (2010) Redoximorphic Features. In: Interpretation of Micromorphological Features of Soils and Regoliths. Elsevier, pp. 129-147. DOI: 10.1016/B9780-444-53156-8.00008-8. 
1032 Loaiza JC, Stoops G, Poch RM, et al. (2015) Manual de micromorfología de suelos y técnicas 1033 complementarias. Fondo Editorial Pascual Bravo: 348.

1034 Macaire JJ, Fourmont A, Argant J, et al. (2010) Quantitative analysis of climate versus human impact 1035 on sediment yield since the Lateglacial: The Sarliève palaeolake catchment (France). The $1036 \quad$ Holocene 20(4): 497-516. DOI: 10.1177/0959683609355181.

1037 MacKenzie WS, Donaldson CH and Guilford C (1982) Atlas of Igneous Rocks and Their Textures. ELBS.

1038 Macphail RI and Goldberg P (2018) Applied Soils and Micromorphology in Archaeology. Barker G, 1039 Slater E, and Bogucki P (eds). Cambridge: Cambridge Manuals in Archaeology-Cambridge $1040 \quad$ University Press.

1041 Macphail RI, Courty M-A and Gebhardt A (1990) Soil Micromorphological Evidence of Early 1042 Agriculture in North-West Europe. World Archaeology 22(1): 53-69.

1043 Magny, Peyron O, Gauthier E, et al. (2009) Quantitative reconstruction of climatic variations during 1044 the Bronze and early Iron ages based on pollen and lake-level data in the NW Alps, France. 1045 Quaternary International 200(1-2): 102-110. DOI: 10.1016/j.quaint.2008.03.011.

1046 Magny M (2004) Holocene climate variability as reflected by mid-European lake-level fluctuations 1047 and its probable impact on prehistoric human settlements. Quaternary International 113: 651048 79. DOI: $10.1016 / \mathrm{S} 1040-6182(03) 00080-6$.

1049 Mayoral A (2018) Analyse de sensibilité aux forçages anthropo-climatiques des paysages 1050 protohistoriques et antiques du plateau volcanique de Corent ( Auvergne ) et de ses marges par 1051 une approche géoarchéologique pluri-indicateurs. Université Clermont Auvergne.

1052 Mayoral A, Peiry J-L, Berger J, et al. (2018) Geoarchaeology and chronostratigraphy of the Lac du Puy 1053 intra-urban protohistoric wetland, Corent, France. Geoarchaeology.

1054 Mayoral A, Peiry JL, Berger JF, et al. (2018) Origin and Holocene geomorphological evolution of the 

landslide-dammed basin of la Narse de la Sauvetat (Massif Central, France). Geomorphology 320. Elsevier B.V.: 162-178. DOI: 10.1016/j.geomorph.2018.08.015.

McCormick M, Büntgen U, Cane MA, et al. (2012) Climate Change during and after the Roman Empire: Reconstructing the Past from Scientific and Historical Evidence. Journal of Interdisciplinary History 43(2): 169-220. DOI: 10.1162/JINH_a_00379.

Mielke JE (1979) Composition of the Earth's crust and distribution of the elements. Review of research on modern problems in geochemistry. Paris: Int. Association for Geochemistry and Cosmochemistry: $13-37$.

Milcent P-Y and Mennessier-Jouannet C (2007) Entre déterminisme environnemental et processus historiques: formes et modalités d'occupation du sol en Basse Auvergne du Bronze Final au début du second Age du Fer. In: Richard H, Magny M, and Mordant C (eds) Environnements et Cultures à l'Âge Du Bronze En Europe Occidentale- Documents Préhistoriques No 21. Paris: CTHS, p. 399.

Milcent P-Y, Poux M, Mader S, et al. (2014) Une agglomération de hauteur autour de 600 a.C. en Gaule centrale : Corent (Auvergne). Transalpinare: 181-204.

Miras Y, Mariani M, Couderc F, et al. (2018) Addressing the complexity of the paleoenvironmental impact of Prehistoric settlement and Protohistoric urbanism in the Auvergne Mountains (Massif Central, France). In: IEMA VOLUME-ARCHAEOLOGY OF MOUNTAIN LANDSCAPES: INTERDISCIPLINARY RESEARCH STRATEGIES OF AGRO-PASTORALISM IN UPLAND REGIONS, 2018.

Nehlig P, Boivin P, De Goër A, et al. (2003) Les volcans du Massif central. Géologues (sp. issue): 1-41.

Nichols K and Gogineni B (2018) The Anthropocene's dating problem: Insights from the geosciences and the humanities. Anthropocene Review 5(2): 107-119. DOI: 10.1177/2053019618784971.

Nicosia C and Stoops G (2017) Archaeological Soil and Sediment Micromorphology. Wiley Blackwell. 
1078 Notebaert, Berger JF and Brochier JL (2014) Characterization and quantification of Holocene colluvial 1079 and alluvial sediments in the Valdaine Region (southern France). Holocene 24: 1320-1335. DOI: 10.1177/0959683614540946.

1081

1082

1083

1084

1085

1086

1087

1088

1089

1090

1091

1092

1093

1094

1095

1096

1097

1098

1099

1100

Notebaert B and Berger J (2014) Quantifying the anthropogenic forcing on soil erosion during the Iron Age and Roman Period in southeastern France. Anthropocene 8(2014). Elsevier B.V.: 59-69. DOI: 10.1016/j.ancene.2015.05.004.

Pagliai M and Stoops G (2010) Physical and Biological Surface Crusts and Seals. In: Interpretation of Micromorphological Features of Soils and Regoliths. Elsevier, pp. 419-440. DOI: 10.1016/B9780-444-53156-8.00019-2.

Passega R (1977) Significance of CM diagrams of sediments deposited by suspensions. Sedimentology 24(5): 723-733. DOI: 10.1111/j.1365-3091.1977.tb00267.x.

Poux M (2012) Corent, Voyage Au Coeur d'une Ville Gauloise. Paris: Editions Errance.

Poux M, Milcent P-Y, Pranyies A, et al. (2018) Corent, Fouille pluriannuelle 2014-2016, Rapport Final d’Opération.

Provost M and Mennessier-jouannet C (1994) Carte archéologique de la Gaule 63-2 Le Puy-de-Dôme. Paris: Ministère de la Culture.

Raynal J, Vernet G and Daugas J (2003) Evolution récente de la Limagne d'Auvergne ( France ) : impacts du volcanisme et aspects des peuplements humains au Tardiglaciaire et à l'Holocène . In: Variazoni climatico-ambientali e impatto sull'uomo nell'area circum-mediterranea durante I'Olocene, Territorio storico et ambiente 3 (eds C Albore-Livadie and F Ortolani), Bari, 2003, pp. 461-475. Edipuglia.

Reimer PJ, Bard E, Bayliss A, et al. (2013) IntCal13 and Marine13 Radiocarbon Age Calibration Curves 0-50,000 Years cal BP. Radiocarbon 55(4): 1869-1887. DOI: 10.2458/azu_js_rc.55.16947. 
1101 Riquier V, Auxiette G, Fechner K, et al. (2015) Éléments de géographie humaine et économique à

1102 l'âge du Bronze et au premier âge du Fer dans la plaine de Troyes. Bulletin de la Société préhistorique française 112(2): 339-367.

Ruddiman WF (2003) THE ANTHROPOGENIC GREENHOUSE ERA BEGAN THOUSANDS OF YEARS AGO. Climatic Change 61: 261-293. DOI: 10.1007/s10584-005-7278-0.

Ruddiman WF (2018) Three flaws in defining a formal 'Anthropocene'. Progress in Physical Geography 42(4): 451-461. DOI: 10.1177/0309133318783142.

Ruddiman WF, Ellis EC, Kaplan JO, et al. (2015) Defining the epoch we live in. Is a formally designated 'Anthropocene' a good idea? Science 348(6230): 38-39. DOI: 10.1126/science.aaa7297.

Sabatier P, Dezileau L, Briqueu L, et al. (2010) Clay minerals and geochemistry record from northwest Mediterranean coastal lagoon sequence: Implications for paleostorm reconstruction. Sedimentary Geology 228(3-4). Elsevier: 205-217. DOI: 10.1016/J.SEDGEO.2010.04.012.

Salminen R, Batista MJ, Bidovec M, et al. (2005) FOREGS Geochemical Atlas of Europe, Part I* Background Information, Methodology, and Maps. Geol. Surv. Finland, Espoo.

Scholle PA and Ulmer-scholle DS (2003) A Color Guide to the Petrography of Carbonate Rocks : Grains, Texture, Porosity, Diagenesis. Tulsa, Oklahoma: American Association of Petroleum Geologists.

Simon F-X, Dousteyssier B, Pareilh-Peyrou M, et al. (2017) Occupation et gestion de l'espace à l'Antiquité en marge d'un ancien centre Arverne, apports des données de prospections sur la villa de Lieu Dieu (Puy-de-Dôme, France) et son espace périphérique. In: Colloque d'Archéométrie, GMPCA, Rennes, 2017.

Spek T, Waateringe WG Van, Kooistra M, et al. (2003) Formation and land-use history of celtic fields in north-west Europe - An interdisciplinary case study at Zeijen, the Netherlands. European 
Journal of Archaeology 6(2): 141-173. DOI: 10.1177/146195710362003.

1125 Stolt MH and Lindbo DL (2010) Soil Organic Matter. In: Interpretation of Micromorphological Features of Soils and Regoliths. Elsevier, pp. 369-396. DOI: 10.1016/B978-0-444-53156-8.00017-9.

Stoops (2003) Guidelines for Analysis and Description of Soil and Regolith Thin Sections. Madison, Wisconsin: Soil Science Society of America.

Stoops G, Marcelino V and Mees F (2010a) Interpretation of Micromorphological Features of Soils and Regoliths. Amsterdam: Elsevier.

Stoops G, Marcelino V and Mees F (2010b) Micromorphological Features and Their Relation to Processes and Classification. In: Interpretation of Micromorphological Features of Soils and Regoliths. Elsevier, pp. 15-35. DOI: 10.1016/B978-0-444-53156-8.00002-7.

Stuiver M and Reimer PJ (1993) Extended 14C database and revised Calib 3.0 14C Age Calibration program. Radiocarbon 35(1): 215-230.

Trément, Argant J, Bréhéret J-G, et al. (2007) Un ancien lac au pied de l’oppidum de Gergovie (Puyde-Dôme). Gallia 64: 289-351.

Trément F (2011) Les Arvernes et Leurs Voisins Du Massif Central à l'Epoque Romaine-Une Archéologie Du Développement Des Territoires, Vol. I. Clermont-Ferrand: Revue D’auvergne, Alliance Universitaire d'Auvergne.

Trément F, Mennessier-Jouannet C, Argant J, et al. (2007) Le bassin de Sarliève : occupation du sol et paléo-environnement à l'âge du Fer. In: L'archéologie de l'âge Du Fer En Auvergne, Actes Du XXVIIe Colloque International de I'A.F.E.A.F. Clermont-Ferrand, pp. 385-400. de-Dôme). Gallia 64: 289-351. 
1146 Usai MR (2001) Textural Pedofeatures and Pre-Hadrian's Wall Ploughed Paleosols at Stanwix, Carlisle,

1147 Cumbria, U.K. Journal of Archaeological Science 28(5): 541-553. DOI: 10.1006/jasc.2001.0609.

1148 Vallat P (2002) Histoire de l'occupation du sol dans la Limagne des buttes (Puy-de-Dôme) de l'Age du 1149 Fer à l'Antiquité Tardive. Université d'Avignon et des pays du Vaucluse.

1150 Van Geel B and Magny M (2002) Mise en évidence d'un forçage solaire du climat à partir de données 1151 paléoécologiques et archéologiques: la transition Subboréal Subatlantique. In: Équilibres et 1152 ruptures dans les écosystèmes durant les 20 derniers millénaires en Europe de l'Ouest (eds H

Vital J (2004) Du Neolithique Final Au Bronze Moyen Dans Le Sud-Est De La France : 2200-1450 Av . J

Vernet Gerard (2013) La séquence sédimentaire des gravanches / gerzat enregistrement d'événements «catastrophiques» À valeur chronologique en limagne d'auvergne (Massif Central, France). Quaternaire 24(2): 109-127. DOI: 10.4000/quaternaire.6519.

1168 Wedepohl KH (1978) Handbook of Geochemistry. Springer-Verlag. 
1169 Welter-Schultes FW (2012) European Non-Marine Molluscs, a Guide for Species Identification = 1170 Bestimmungsbuch Für Europäische Land- Und Süsswassermollusken. Gottingen: Planet Poster

$1171 \quad$ Editions. Available at: https://www.nhbs.com/european-non-marine-molluscs-a-guide-for-

1172 species-identification-bestimmungsbuch-fur-europaische-land-und-susswassermollusken-book $1173 \quad$ (accessed 29 January 2019).

1174 Whittle A, Rouse AJ, Evans JG, et al. (1993) A Neolithic Downland Monument in its Environment:

1175 Excavations at the Easton Down Long Barrow, Bishops Cannings, North Wiltshire. Proceedings of

1176 the Prehistoric Society 59. Cambridge University Press: 197-239. DOI:

$1177 \quad 10.1017 / S 0079497 \times 00003790$.

1178 Zamanian K, Pustovoytov K and Kuzyakov Y (2016) Pedogenic carbonates: Forms and formation 1179 processes. Earth-Science Reviews 157. Elsevier B.V.: 1-17. DOI:

$1180 \quad$ 10.1016/j.earscirev.2016.03.003. 
Complex : subangular blocky to crumbly, spongy aggregates, poorly accomodated. Moderately separated and aggregated. Abundant vughs, some polyconcave. Very abundant small channels $(64-70 \mathrm{~cm})$.

$$
\text { prismatic. }
$$

Subangular blocky to granular, slightly crumbly. Poorly to

moderately aggregated and small channels (rarely bigger) Several vughs and rare chambers. rare volcanic minerals and quartz fine sands. Abundant to very abundant biospheroids, few

Subangular to angular blocky, moderately separated and well

aggregated. Secondary structure (top) and small channels (centerbase).

limestone and quartz-felds. silts to fine sands, rarely basaltic. Abundant orthic $(64-70 \mathrm{~cm})$. Several chara oogons. Several big orthic tuffaceous concretions. (70$74 \mathrm{~cm}$ ). quartz-felds. Few biospheroids, very abundant malacoremains, few ostracods
oogons.

Rare basaltic and scoria sands, rare volcanic

$-64-70 \mathrm{~cm}$ : Yellowish to

reddish brown, dark

brown areas. Very
organic and densely

malacorem dotted and speckled. micromass $(64-70 \mathrm{~cm})$ Several biospheroids, Microsparite grains.

Injections of beige

micromass rich in calcite and diatoms. $-70-74 \mathrm{~cm}$ : Less organic even tuffaceous.

Rare basaltic and scoria sands to granules, rare volcanic minerals and quartz fine sands.
Several limestone medium to coarse sand. to several malacoremains, rare phytoliths.

Few limestone silt to fine sand, few to rare minerals. Several limestone sand, few quartzfeldspar sands. Very big and abundant biospheroids, some very well-rounded. Few

Clayey, dark brown to black, very organomanganic, very densely dotted (obscured). Abundant microsparite grains.

Clayey, light brown to yellowish brown, sometimes reddish speckles. Dotted w dark particles. Microsparite grains.

Clayey, yellowish to dotted with dark particles.

Some quartz-felds. silt to fine sand, several limestone silt to medium sand. Some biospheroids, few malacoremains, rare phytoliths.
Extremely abundant small to medium (6) (top) $\quad 70 \mathrm{~cm}$ ). Abundant micro and I macrocharcoal, some millimetric (64.70 CC cm). Very abundant amorphous OM and organic pigment. Few small bone fragments.
Very abundant calcite fine coatings and infillings of voids. Several micritic pseudomorphs of chara, more abundant and more microsparitic between 70 and 74 $\mathrm{cm}$. Abundant and variegated tuffaceous concretions micritic to microsparitic (especially $70-74 \mathrm{~cm}$ ), including phytoliths and diatoms. Extremely abundant small big and diffuse manganic nodules, moderately to strongly impregnated.
Very abundant microcharcoal, several to abundant macrocharcoal. Very

CC abundant fine $\mathrm{OM}$, and very abundant and variegated remains of tissues (brown, reddish brown and black).

Abundant microcharcoal, few CC macrocharcoal. Abundant reddish mporhous OM remains and pigment one bone fragment.

Very abundant and very fine calcite coatings of voids. Several small to medium sparite nodules, some small and irregular iron impregnative nodules. Few irregular and diffuse nodules, some small and irregular iron impregnative nodules. Few irregular and diffuse
iron hypocoatings. Abundant tubular injections of micromass from upper levels (beige one bone fragnent. greyish brown, rare reddish areas. Densely Very abundant microsparite grains. Strong micritisation (base).

Abundant to very abundant microcharcoal, several macrocharcoal, one big bone fragment. Abundant fine amorphous OM, and several brownish or reddish fragments of tissues and rootlets, several reddish spores.

Abundant microcharcoal, abundant Clayey yellowish brown Microsparite grains. sometimes reddish or
Abundant fine calcite coatings of voids. Abundant small sparite nodules. Few injections of beige micromass from upper levels, rich in diatoms. Very abundant big brown pedogenic aggregates, very irregular, from underlying SU. rounded, disorthic to anorthic. Several small and diffuse iron impregnative nodules, rare iron quasi-coatings of big channels. Several diffuse manganic nodules, poorly to moderately impregnated, irregular or roughly dendritic. Few to several matrix injections from upper levels (beige rich in diatoms, or black rich in OM and charcoal).

Very fine calcite coatings of voids, several loose and discontinuous micrite infillings of fine porosity. Very rare calcite nodules, anorthic. Several diffuse manganic nodules, weakly to well impregnated, rounded to dendritic. Rare orthic microlaminated clay coatings, partly oriented, limpid to dusty. Few matrix injections from upper levels (beige rich in diatoms, or black rich in OM and charcoal). 
Subangular blocky to granular,

I $\quad$ poorly separated and aggregated

subangular sedondary structure.

Rare vughs, very abdt. small channels

$1 / 20 \quad 0$

Rare volcanic grains, very abundant silts, some Clayey, greyish to carbonad fine yellowish brown, rarely ceddish, dotted by dark quart/fids. sils, rarely fine sands. Few phytoliths

particles, micritisation reas (esp. 113-114 cm) and microsparite grain

macrocharcoal, abundant fine amorphous OM. Some reddish spores.
Organic pigment and abundant small reddish and brownish debris

Rare medium to coarse basaltic sand, well rounded. Very abundant limestone silt to

Subangular to angular blocky well separated and aggregated. Very abundant small channels, rare vughs.

Silt to fine sand Several malacoremains, few biospheroids.

Subangular blocky to granula weakly separated and aggregated.
Abundant small channels, some vughs, rare vesicles. minerals. Very abundant limestone silts to coarse sand, abundant quartz-felds. Silt to fine sand. Few malacoremains, few to several biospheroids.

Clayey, yellowish to reddish brown, with greyish areas, dotted. Microsparite grains.
Abundant microcharcoal, few macrocharcoal, abundant small

CC fragments of amorphous OM, abundant reddish pigment, abundant small reddish brown fragments of tissues.
Very fine calcite coatings of voids, several micrite hypo-coatings of channels. Several to abundant micritic to sparitic irregular nodules, orthic to disorthic, unevenly developed. Some iron quasicoatings and hypocoatings of channels. Several very small and diffuse impregnative iron nodules. Several manganic nodules moderately to strongly impregnated, rare OM-rich matrix injections from upper horizons.

Abundant very fine calcite coatings of voids, rarely associated with iron diffuse hypocoatings around small channels. Sometimes partial calcite infillings. Several micritic to sparitic irregular nodules, orthic to disorthic. Several orthic manganese nodules, diffuse and weakly impregnated. Rare fragments of dusty, poorly-oriented clay coatings, anorthic. Few clusters of mite droppings, linked to organic remains. Rare inclusions of OM-rich dark matrix with microcharcoal.
Subangular blocky, weakly to moderately aggregated and

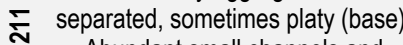
Abundant small channels and channels to massive (base)
chans (top), but sometimes rare

Subangular to angular blocky, moderately to well aggregated and

separated very few channels, few vughs.
Clayery, yellowish brown, some greyish or reddish areas. Dotted by dark particles. Microsparite grains.
Abundant microcharcoal, one big $\mathrm{CC}$ to macrocharcoal. Fine amporphous $\mathrm{OM}$. SP Rare reddish fragments from tissues pugment. Two bone fragments.
Abundant very fine calcite coatings on voids, abundant middle-sized calcite nodules, microsparitic to sparitic, concentrated c. 140-142 cm, orthic to disorthic. Several very diffuse and weakly impregnated manganic nodules, typic to dendritic, very rare ferromanganic well impregnated nodules. Some diffuse micritic or manganic hypohypocoatings of porosity.
Few basaltic fine to coarse sand, well-rounded, and rare scoria fine sand Very abundant limestone silt to fine sand, subangular to rounded. Abundant quartz-folds silt to fine sand subangular to rounded. Few biospherid (absent at base), several malacoremains.

Clayey, yellowish brown with greyish and reddish areas, dotted. Microsparite grains and
micritisation areas (base)
Abundant microcharcoal, few macrocharcoal. Several fine amorphous $\mathrm{CC}$ to $\mathrm{OM}$ and reddish organic pigment. SP Abundant small reddish fragments of tissues and rootlets. One bone fragment.

bundant very fine calcite coatings of voids. Few to several micritic to sparitic calcite nodules, orthic to disorthic. Few diffuse manganic nodules, weakly to moderately

Several microcharcoal, rare Several basaltic and scoria fine to medium sand, often well rounded. Abundant quartzfelds. silt to fine sand. Very abundant limestone medium to coarse sand. Rare sand-sized fragments of granite and flint. Very rare biospheroids, and several malacoremains.
Clayey, yellowish brown greyish areas, dotted. Microsparite grains.
Several microcharcoal, rare macrocharcoal. Few to several fine pigment. Several reddish small fragments of rootlets and tissues.
Abundant fine calcite coatings of voids. Rare laminated calcite coatings of coarse particles, anorthic. Rare sparitic calcite nodules, anorthic. Abundant tuffaceous concretions remains (tubes), anorthic. Rare diffuse manganic nodules. One dusty clay coating fragment, anorthic. Some big clayey pedogenic aggregates, elongated and with diffuse borders, with striated $\mathrm{BF}$ (crust), anorthic. Abundant clusters of mite droppings, associated to organic debris. 
Sand: Several small scoria, abundant basalt, abundant quartz and feldspar, extremely Single-grain $\quad \mathrm{CP}$ abundant and coarse limestone grains, some

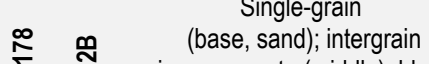

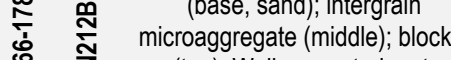
(top). Well separated, not aggregated.

$\mathrm{CP}$ abundant and coarse limestone grains, some $\begin{array}{cccc} & \text { (top) } & \text { sparite fragments. Several small volcanic } & \text { If present, clayey, } \\ 9 / 10 & \mid \mathrm{EG} / & \text { minerals (olivine, pyroxene, nepheline). Few } & \text { yellowish brown, dotted }\end{array}$ flint and rare granite (base) malacormains, very abundantbiosherids malacoremains, very abundant biospheroids
well-rounded and with micrite coatings.

Several basaltic and scoria fine to coarse sand well-rounded. Several volcanic minerals Fissural structure to subangular including nepheline. Several quartz-felds. sand. $\stackrel{m}{\sim}$ blocky, very poorly separated and $3 / 4 \quad$ CP $\quad$ Few small fragments of flint, and rare of granite

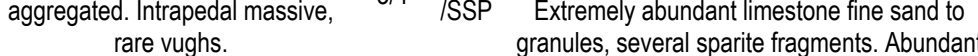
framented malaremains, roughly bedded. Several well-rounded biospheroids.
Clayey, yellowish to greyish brown, dotted. Microsparite grains.
Rare microcharcoal, few macrocharcoal, Calcite coatings of most sand grains, sometimes polyphased (pisolithe-like), anorthic. CC rare fine amorphous OM. Few Reddish Few chara pseudomorphs, anorthic. Several well-rounded sparitic nodules, anorthic. (top) fragments of tissues. Few to several Several pedosedimentary fragments of clay infillings/coatings with variegated features. small to medium-sized bone fragments. microsparite grains.
Rare fine calcite coatings of voids. Few small sparitic nodules, orthic. Abundant microlaminated micritic coatings of sands, pisolith-like (top). Few organo manganic nodules, strongly impregnated. Few mite droppings. Some well-rounded anorthic pedosedimentary aggregates, with variegated characteristics. Rare tube-like tuffaceous concretions, anorthic.

\section{abundant macrocharcoal. Rarely} reddish organic pigment and fine

amorphous OM. Few reddish fragments fragments (up to $3 \mathrm{~mm}$ )
Abundant basaltic coarse sand, few scoria.

Several to abundant volcanic minerals

MG (nepheline, analcime). Several quartz/felds. fine

Single-grain (top, sand), to fissural $3 / 4$ to (top)/ to coarse sand, and extremely abundant (base) Well separated not $\quad 1 / 5 \quad \mathrm{CP}$ limesto fine to coarse sand Abunclant sparie aggregated (base) (base) OP crystals, and some tube-like tuffaceous

(base) concretions. Rare small flint fragments. Severa
If present, clayey, yellowish to greyish brown, finely doted, microsparite grains.
Several microcharcoal, few to several macrocharch Fine CC Some reddish fragments fom roolles sized bone fragments. and tissues Severl small to rollo 

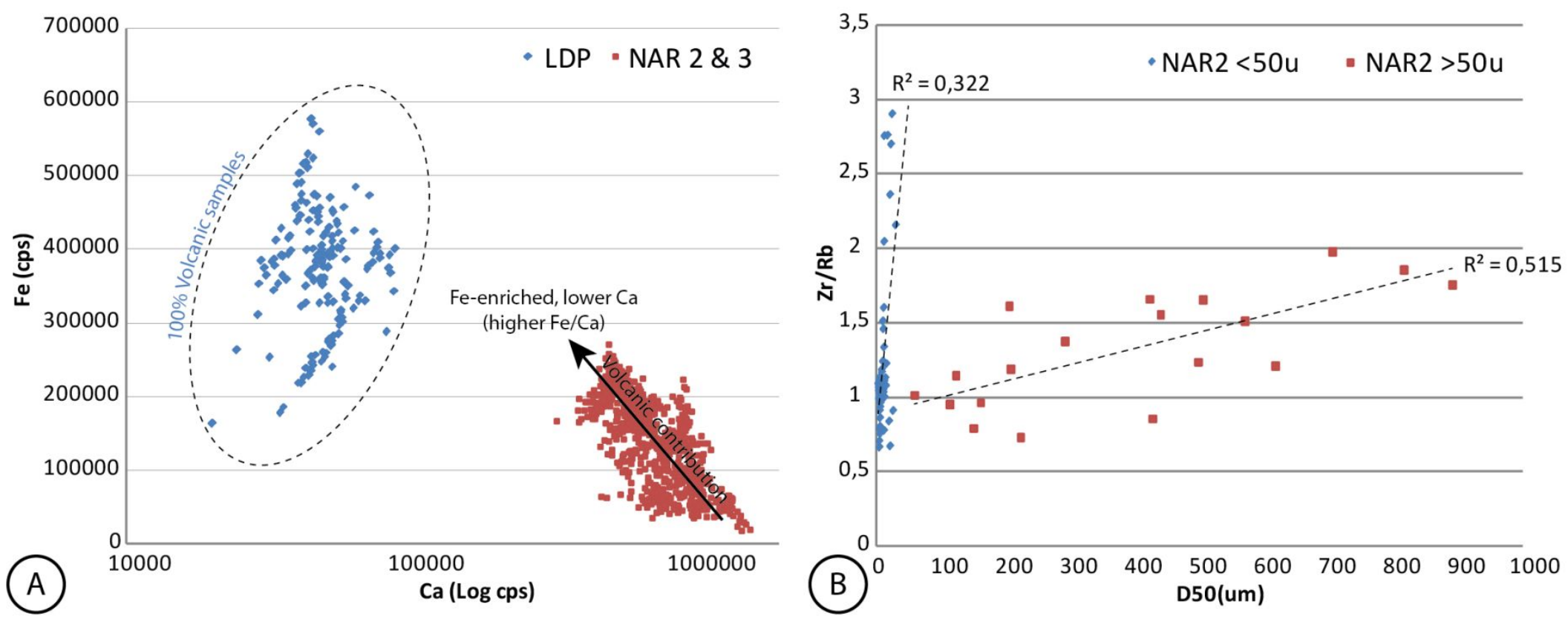

2 figure 12. A) Scatterplot showing relative contents in Fe and Ca (measured by XRF core-scanner in cps, Log scale for Ca) of $100 \%$ volcanic samples (LDP blue dots, core from the summit of the Puy de Corent, lithology: basalts 28

2 and scoria, data from Mayoral, 2018), vs. samples from NAR2 \& NAR3 in the calcareous lowlands (this study, red dots). 100\% volcanic samples have clearly higher Fe/Ca ratio. Note also the gradient in the Fe/Ca ratio for 3QNAR2 \& NAR3 samples interpreted as increased volcanic sediment content. B) Scatterplot showing relationship between Zr/Rb ratio and D50 in NAR2 samples, for two different grain-size classes. Zr/Rb is very sensitive to 31

32rain-size increase in clays and fine to coarse silts ( $<50 u m$, blue dots), and moderately sensitive for very coarse silts and sands ( $>50$ um, red dots). Note that relatively low $R^{2}$ is mainly due to the reduced number of samples. 


\begin{tabular}{|c|c|c|c|c|c|c|c|c|c|c|c|c|c|c|c|c|c|c|}
\hline ] & Sedimentary subunit & 2.24 & 2.23 & 2.22 & 2.21 & 2.20 & 2.19 & 2.18 & 2.17 & $2.16 \mathrm{inf}$ & 2.16 sup & 2.15 & 2.14 & 2.13 & 2.12 & 2.11 & 2.10 & 2.9 \\
\hline 2 & Depth $(\mathrm{cm})$ & $196-202$ & 194-196 & $186-194$ & $180-184$ & $170-178$ & $164-170$ & $158-162$ & $154-158$ & $142-154$ & $132-142$ & $122-132$ & $114-122$ & $100-114$ & $90-100$ & $86-90$ & $80-84$ & $70-78$ \\
\hline \multirow{4}{*}{$\mathrm{F}$} & Arianta arbustorum & 1 & 4 & 2 & 1 & 2 & 1 & & 1 & 1 & 1 & 1 & 1 & 1 & 1 & & & \\
\hline & Clausilia sp. & & 1 & 2 & 1 & 1 & 1 & & 1 & & & & & & & & & \\
\hline & Discus rotundatus & & & 1 & & 1 & & & & & & & & & & & & \\
\hline & Pomatias elegans & 1 & 1 & 5 & 4 & 2 & 1 & & & 1 & 1 & & & & & & & \\
\hline \multirow{4}{*}{$1 p_{M}$} & $\begin{array}{r}\text { Cochlicopa lubrica } \\
\text { agg. }\end{array}$ & 5 & 4 & 6 & 6 & 3 & 3 & 1 & 1 & 11 & 9 & 6 & 7 & 2 & 2 & & & 1 \\
\hline & Slugs & 22 & 6 & 17 & 1 & 7 & 3 & 1 & 1 & 6 & 1 & 5 & 5 & 2 & 2 & & 1 & 2 \\
\hline & $\begin{array}{l}\text { Nesovitrea } \\
\text { hammonis }\end{array}$ & & 1 & & & & & & & & & & & & & & & \\
\hline & Punctum pygmaeum & & 1 & 1 & & & & & & & & 1 & 2 & & & & & \\
\hline \multirow{2}{*}{13} & Trochulus hispidus & & & & 2 & 1 & & & & & & 1 & 6 & 3 & 8 & 1 & 5 & 2 \\
\hline & Vallonia costata & 6 & 5 & 5 & 4 & 4 & 2 & & 2 & 2 & 6 & 3 & 4 & 5 & 6 & 7 & 4 & 5 \\
\hline \multirow{5}{*}{$\begin{array}{l}14 \\
15 \\
15 p \\
17 \\
18\end{array}$} & Carychium minimum & & & & & 1 & & & & & 15 & 34 & 59 & 10 & & & 1 & \\
\hline & Oxyloma elegans & 9 & 2 & 7 & & 3 & 3 & 1 & 1 & 2 & 15 & 4 & 10 & 6 & 3 & 1 & & 2 \\
\hline & Vertigo angustior & 2 & 1 & & 1 & & Pr & & & & & & & & & & & \\
\hline & Vertigo antivertigo & 7 & & & & & 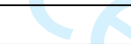 & 1 & & 1 & 8 & 11 & 14 & & & & & \\
\hline & Zonitoides nitidus & 3 & 2 & & & & 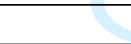 & 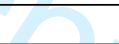 & & & 1 & 1 & 1 & & & & & \\
\hline \multirow{4}{*}{$\begin{array}{l}19 \\
20 \\
21 \\
22\end{array}$} & Chondrula tridens & & 1 & 1 & & 1 & & +9 & & & & & & & & & & \\
\hline & Helicella itala & 2 & & 14 & & 1 & 2 & 1 & 3 & 3 & 2 & & & 1 & 1 & 1 & & 2 \\
\hline & Pupilla muscorum & 9 & 10 & 9 & 5 & 4 & 2 & 1 & 1 & 5 & 2 & 1 & & 1 & 1 & 3 & 1 & 1 \\
\hline & Vallonia excentrica & 17 & 3 & 5 & 8 & & 6 & & 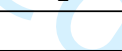 & 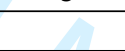 & & & & & 6 & 19 & 23 & 5 \\
\hline \multirow{2}{*}{$\begin{array}{l}2 \beta \\
24\end{array}$} & Vallonia pulchella & & 8 & 13 & & 10 & 6 & 5 & 9 & 46 & 154 & 39 & 77 & 14 & 11 & & & 7 \\
\hline & Vertigo pygmaea & & 2 & 4 & 2 & & & 4 & 1 & 7 & 5 & 1 & 4 & 3 & 4 & 2 & 4 & 4 \\
\hline \multirow{2}{*}{$\begin{array}{l}25 \\
25\end{array}$} & Acroloxus lacustris & & & & & & & & & 0 & $x^{2}$ & & & & & & & 4 \\
\hline & Ancylus fluviatilis & & 1 & & & & & & & & 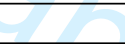 & & & & & & & \\
\hline \multirow{2}{*}{27} & Anisusleucostoma & 4 & & 2 & 1 & & 4 & 4 & 1 & 2 & 13 & 39 & 65 & 28 & 2 & & & 7 \\
\hline & Galba truncatula & 11 & 10 & & & & 2 & 1 & 2 & 19 & 79 & 15 & 18 & 17 & & & & 3 \\
\hline \multirow{2}{*}{29} & Gyraulus albus & 1 & 1 & 2 & 1 & & & 1 & 1 & & & 1 & 2 & 6 & 1 & & & 4 \\
\hline & Gyraulus crista & 19 & 12 & 7 & & & & 1 & & & & 2 & 3 & 5 & 1 & 1 & 2 & 57 \\
\hline $30 \mathrm{~A}$ & $\begin{array}{r}\text { Hippeutis } \\
\text { complanatus }\end{array}$ & & & & & & & & & & & 1 & 3 & 4 & & & & 8 \\
\hline \multirow{2}{*}{32} & Lymnaea stagnalis & 1 & & & & & & & & & & & & 2 & & & & \\
\hline & Physa fontinalis & & & & & & & & & & & 2 & 2 & 2 & & & & 2 \\
\hline 34 & Pisidium sp. & 27 & 16 & 32 & 16 & 10 & 19 & 11 & 2 & 2 & 1 & 5 & 8 & 4 & & & & 3 \\
\hline 35 & Radix balthica & 20 & 8 & 1 & 4 & 3 & 7 & 3 & & & 21 & 10 & 4 & 5 & 1 & & & 11 \\
\hline 36 & Valvata cristata & & & & & & & & & & & & & 1 & & & & 1 \\
\hline 37 & Count & 167 & 100 & 136 & 57 & 54 & 62 & 36 & 27 & 108 & 334 & 183 & 295 & 120 & 50 & 35 & 41 & 131 \\
\hline 38 & Cecilioides acicula & & & & & & & & & 3 & & & & & & & & \\
\hline
\end{tabular}

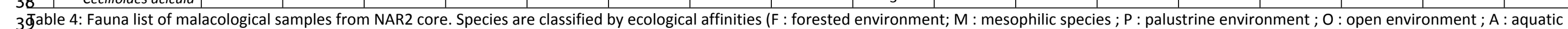
$4 \Theta$ pecies) and by alphabetical order. 


\begin{tabular}{|c|c|c|c|c|c|c|c|c|c|c|c|c|c|c|c|c|}
\hline \multirow{2}{*}{$\begin{array}{l}2 \\
3 \\
4\end{array}$} & \multirow{2}{*}{$\begin{array}{r}\text { Sedimentary subunit } \\
\text { Depth }(\mathrm{cm})\end{array}$} & \multirow{2}{*}{$\begin{array}{l}3.13 \\
193- \\
201\end{array}$} & \multicolumn{3}{|c|}{3.12} & \multicolumn{2}{|l|}{3.11} & \multirow{2}{*}{$\begin{array}{l}3.10 \\
147- \\
156\end{array}$} & \multicolumn{3}{|l|}{3.9} & \multicolumn{2}{|c|}{3.8} & \multirow{2}{*}{$\begin{array}{c}3.7 \\
104- \\
112\end{array}$} & \multicolumn{2}{|c|}{3.6} \\
\hline & & & $187-193$ & $\begin{array}{l}181- \\
187\end{array}$ & $\begin{array}{l}174- \\
181 \\
\end{array}$ & $165-171$ & $\begin{array}{l}159- \\
165 \\
\end{array}$ & & $140-147$ & $\begin{array}{l}134- \\
140 \\
\end{array}$ & $\begin{array}{l}128- \\
134 \\
\end{array}$ & $120-128$ & $\begin{array}{l}114- \\
120 \\
\end{array}$ & & $92-103$ & $\begin{array}{l}84- \\
92\end{array}$ \\
\hline 5 & Arianta arbustorum & & 1 & 1 & 1 & 3 & 2 & 9 & 1 & 1 & 1 & 1 & 1 & 1 & & \\
\hline $\mathrm{F}$ & Clausilia sp. & & & & & & & & 1 & & & & & & & \\
\hline 7 & Pomatias elegans & & & & 1 & 1 & & & & & & 1 & & & & \\
\hline 8 & $\begin{array}{r}\text { Cochlicopa lubrica } \\
\text { agg. }\end{array}$ & & & 3 & 4 & 10 & 12 & 29 & 16 & 11 & 7 & 5 & 5 & 5 & 3 & 3 \\
\hline 9 & Slugs & 6 & 4 & 13 & 20 & 32 & 29 & 75 & 59 & 38 & 21 & 25 & 16 & 12 & 4 & 2 \\
\hline 10 & Nesovitrea hammonis & & 1 & & & 2 & 1 & 4 & 2 & & & & & & & \\
\hline $1 \mathrm{~h}^{\mathrm{M}}$ & Punctum pygmaeum & & & & 1 & & 1 & 2 & 1 & 1 & & & 2 & & & \\
\hline 12 & Trochulus hispidus & & & & & & & & 1 & & & 2 & 5 & 1 & 5 & 1 \\
\hline $1 \beta$ & Vallonia costata & 3 & & 6 & 7 & 11 & 7 & 35 & 12 & 6 & 1 & 3 & & & & \\
\hline 14 & Vitrina pellucida & & & & 1 & 1 & 1 & & & & & & & & & \\
\hline 15 & Carychium minimum & & 1 & 4 & 10 & 28 & 32 & 25 & 3 & 2 & & & 4 & 16 & 1 & \\
\hline 16 & Oxyloma elegans & 1 & & & 8 & 11 & 14 & 44 & 24 & 15 & 15 & 10 & 9 & 18 & 18 & 6 \\
\hline pp & Vertigo angustior & & & 1 & 4 & 9 & 16 & 4 & 1 & & & & 1 & 1 & & \\
\hline TP & Vertigo antivertigo & 2 & & 5 & 11 & 20 & 31 & 22 & 8 & 10 & 2 & 2 & 5 & 21 & 5 & \\
\hline 18 & Vertigo moulinsiana & & & & & & + & 1 & $\overline{0}$ & & & & & & & \\
\hline 19 & Zonitoides nitidus & & & 1 & 2 & 4 & 6 & 1 & 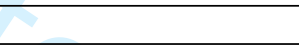 & & & & & 4 & 8 & \\
\hline 20 & Helicella itala & & 8 & & 1 & & 3 & 12 & 20 & 16 & 2 & 9 & 5 & 4 & & \\
\hline 21 & Pupilla muscorum & 3 & 5 & 6 & 2 & 7 & 7 & 29 & 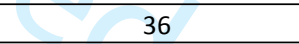 & 21 & 8 & 7 & 10 & 7 & & \\
\hline 220 & Vallonia excentrica & & & & & & & & 15 & 8 & & & & & & \\
\hline $2 \beta$ & Vallonia pulchella & 20 & 55 & 73 & 102 & 100 & 126 & 202 & 252 & 182 & 44 & 23 & 104 & 95 & 18 & 15 \\
\hline 24 & Vertigo pygmaea & & 6 & 4 & 8 & 17 & 19 & 20 & 29 & 22 & 4 & 6 & 23 & 11 & 2 & \\
\hline 25 & Acroloxus lacustris & & & & & & & & & & & & & & 6 & 12 \\
\hline 26 & Anisus leucostoma & & & & & 3 & & 2 & 1 & 2 & 1 & & 4 & 16 & 34 & \\
\hline 27 & Galba truncatula & 1 & & 3 & 14 & 28 & 21 & 7 & 6 & 32 & 24 & 9 & 28 & 57 & 48 & 17 \\
\hline 8 & Gyraulus albus & & & & & & & & & & & & & & 13 & 31 \\
\hline 20 & Gyraulus crista & & & & 3 & 9 & 3 & 2 & 3 & 1 & 2 & & & 1 & 74 & 112 \\
\hline 39 & $\begin{array}{r}\text { Hippeutis } \\
\text { complanatus } \\
\end{array}$ & & & & & & & & & & & & & & 9 & 9 \\
\hline $31^{\mathrm{A}}$ & Lymnaea stagnalis & & & & & & & & & & & & & & & 2 \\
\hline 32 & Physa fontinalis & & & & & & & & & & & & & 3 & 8 & \\
\hline $3 \beta$ & Pisidium sp. & 2 & 1 & 1 & 1 & 5 & 4 & 2 & & & & & 2 & 18 & 35 & 13 \\
\hline 34 & Planorbis planorbis & 1 & & 1 & & & & & 1 & & & & & 13 & 26 & 26 \\
\hline 35 & Radix balthica & & & & & 4 & 1 & & & & & & 2 & 18 & 27 & 22 \\
\hline 36 & Radix labiata & 1 & 4 & 3 & 10 & 23 & 36 & 45 & 39 & 21 & 2 & & & & & \\
\hline 30 & Valvata cristata & & & & & & & & & & & & & & 2 & 14 \\
\hline 36 & Count & 40 & 86 & 125 & 211 & 328 & 372 & 572 & 519 & 389 & 134 & 103 & 226 & 319 & 346 & 285 \\
\hline 38 & Cecilioides acicula & & & 1 & & & & & 1 & 1 & 1 & & & & & \\
\hline
\end{tabular}

39able 5: Fauna list of malacological samples from NAR3 core. Species are classified by ecological affinities ( F : forested environment; M : mesophilic species ; P : palustrine environment ; 0 : open environment ; A : aquatic $4 \varrho_{\text {pecies }}$ and by alphabetical order. Grey columns indicate samples which were grouped in order to reach a number in accordance with the representativeness threshold of Evans (1972) 
Figure 1. A) Location of study area, black line delineates Auvergne region; B) General view of study area from the summit of the Puy de Corent (location: see Fig. 1C, view direction: ESE). La Narse hydromorphic basin and its catchment are indicated with white and red dashed lines respectively. Light blue dashed line indicates hypothetical position of former river course (Pleistocene and Early Holocene), from cross sections and current topography (see Mayoral et al., 2018); C) Geomorphological sketch of la Narse de la Sauvetat catchment (modified from Mayoral et al., 2018) ; D) Main soils of the catchment (red dashed line) following

Bornand et al., 1968 : a) lithosols and brown soils on basalts ; b) Calcareous and calcic brown soils on marls and basaltic colluvium ; c) Colluvial soils and regosoils on marls and platy limestone ; d) Calcareous brown soils on gentle slopes ; e) Clayey grey soils of marly depressions, hydromorphic and isohumic; f) Calcareous brown soils from thin residual terraces; g) Gleyic soils from clayey alluvium of streams and marly lowlands.

$410 \times 405 \mathrm{~mm}(300 \times 300 \mathrm{DPI})$ 


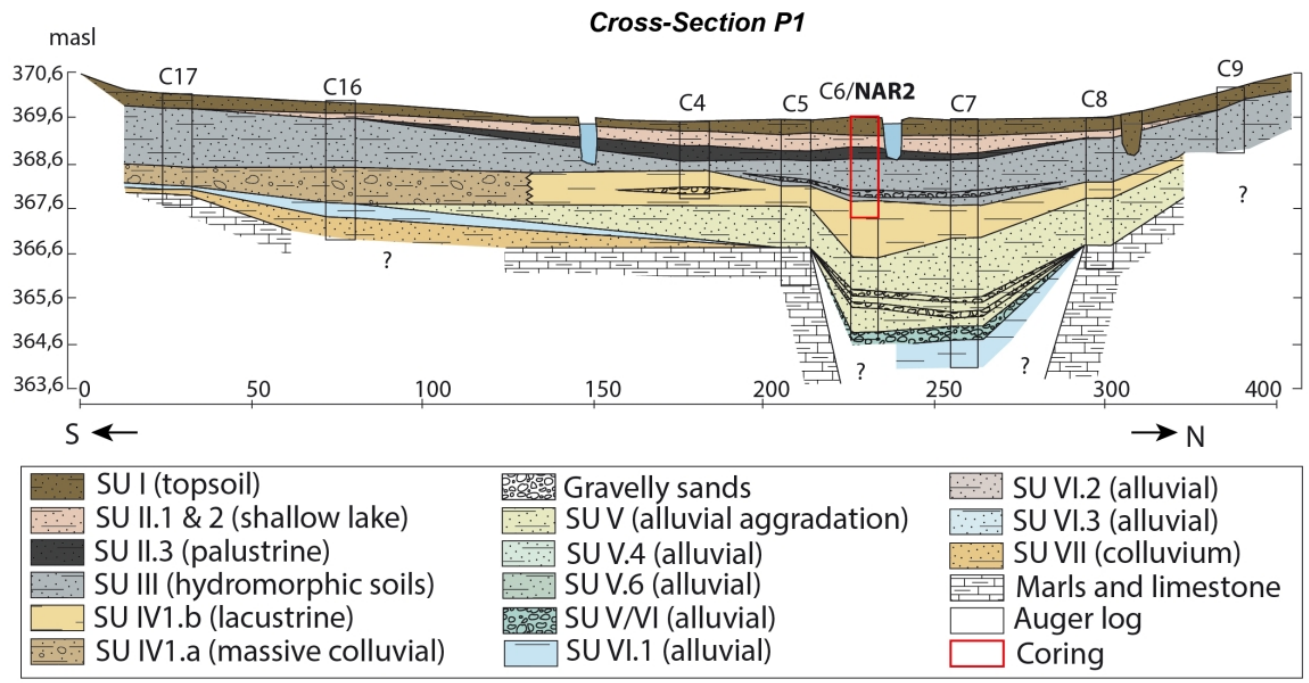

Cross-Section P2

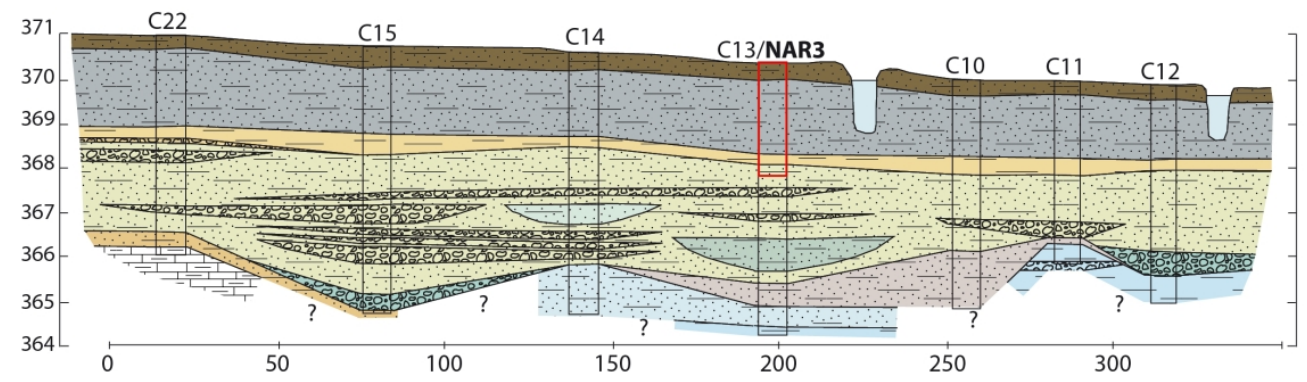

Figure 2. Selected stratigraphic cross-sections of the basin (P1 and P2, adapted from Mayoral et al., 2018) with location of cores NAR2 and NAR3 (see also Fig. 1C).

$210 \times 181 \mathrm{~mm}(300 \times 300 \mathrm{DPI})$ 


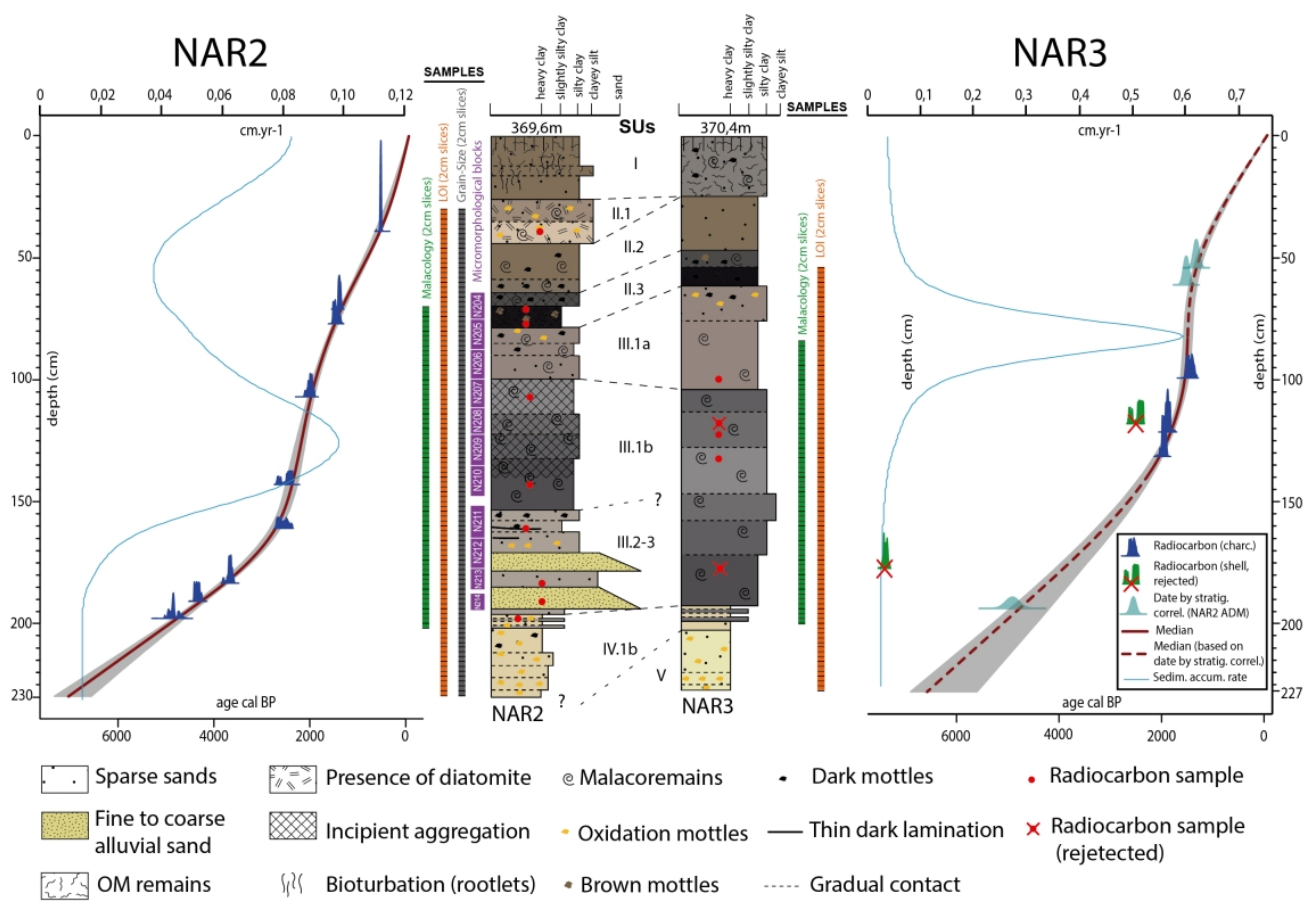

Figure 3. Litho-stratigraphy, stratigraphic correlations, sampling and age-depth model of NAR2 (left) and NAR3 (right) cores.

$242 \times 168 \mathrm{~mm}(300 \times 300 \mathrm{DPI})$ 

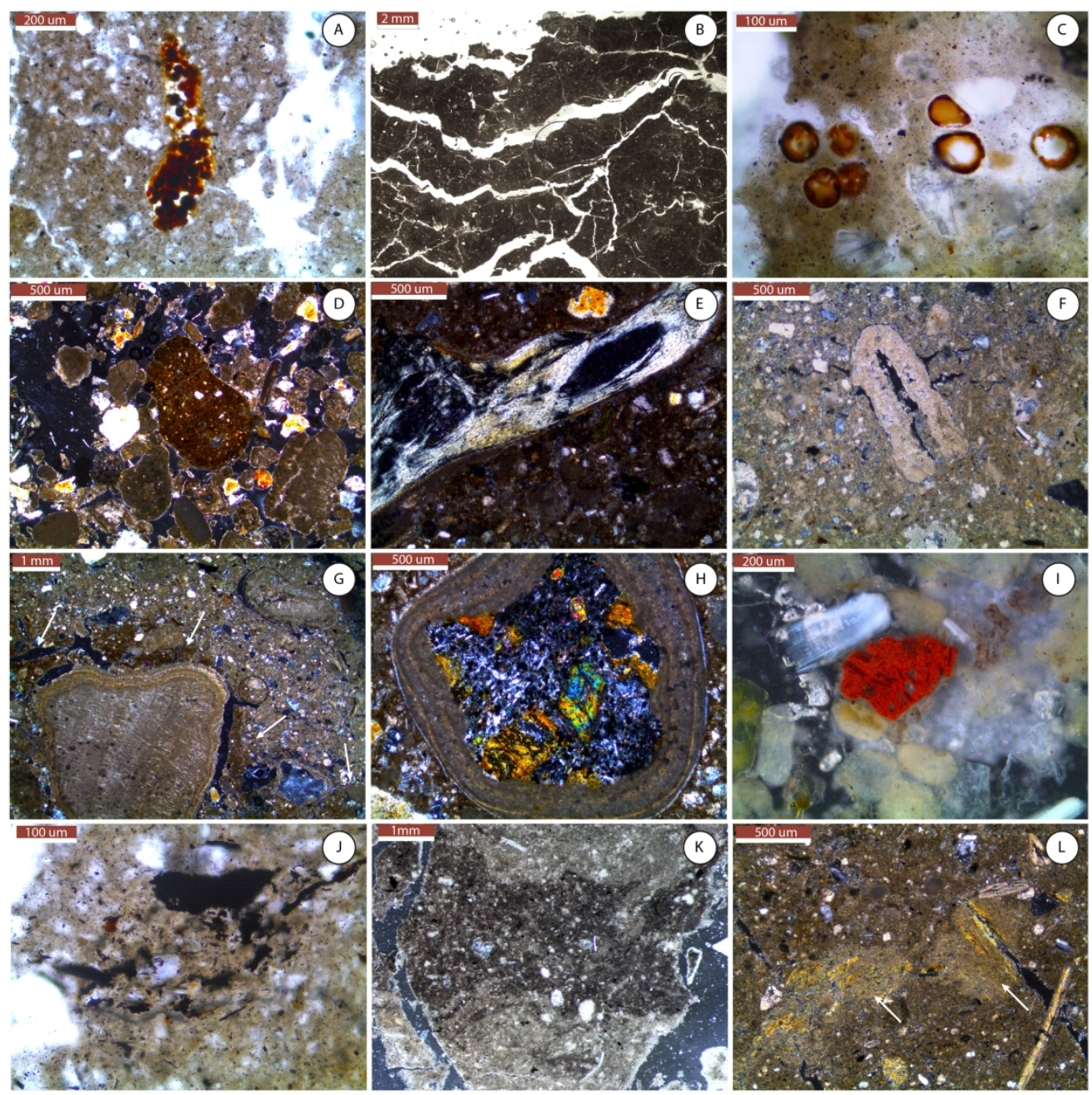

Figure 4. Selected micromorphological features of lower NAR2 (Micromorphological Units MVII to MIV, see text and Fig. 6). A) Cluster of mite droppings, microcharcoal-rich micromass (MIV, N211, PPL-Plane Polarized Light). B) Platy microstructure (MIV, N211, transmitted light). C) Spore remains (MIV, N211, PPL). D) Rounded pedosedimentary aggregate (reddish matrix), surrounded mainly by carbonated micritic sands (MV, N212B, XPL-Crossed Polarized Light). E) Bone fragment (MVI, N213, XPL). F) Fragment of micritic to micro-sparitic carbonated root concretion (MIV, N212A, XPL). G) Contact (arrows) of coarse sands with silty clays. Note the big stromatolitic/tuffaceous fragment of limestone, with a secondary microlaminated calcite coating (MV, N212B, XPL). H) Fragment of basalt with a coating of microlaminated calcite (micrite and microsparite) and rounded by transport (MVI, N213, XPL). I) Volcanic reddish scoria fragment, including translucent plagioclases (MV, N212B, OIL-Oblique Incident Light). J) Cluster of charcoal and in-situ charred remains (MIV, N211, PPL). K) Portion of dark matrix, with more abundant coarse fraction, more humic and

enriched in microcharcoal, probably from a surficial soil horizon (MIV, base of N211, OIL). L) Clayey aggregates with striated B-Fabric (arrows), likely degraded fragments of slaking crust (MIV, N212A, XPL).

$286 \times 288 \mathrm{~mm}(300 \times 300$ DPI $)$ 


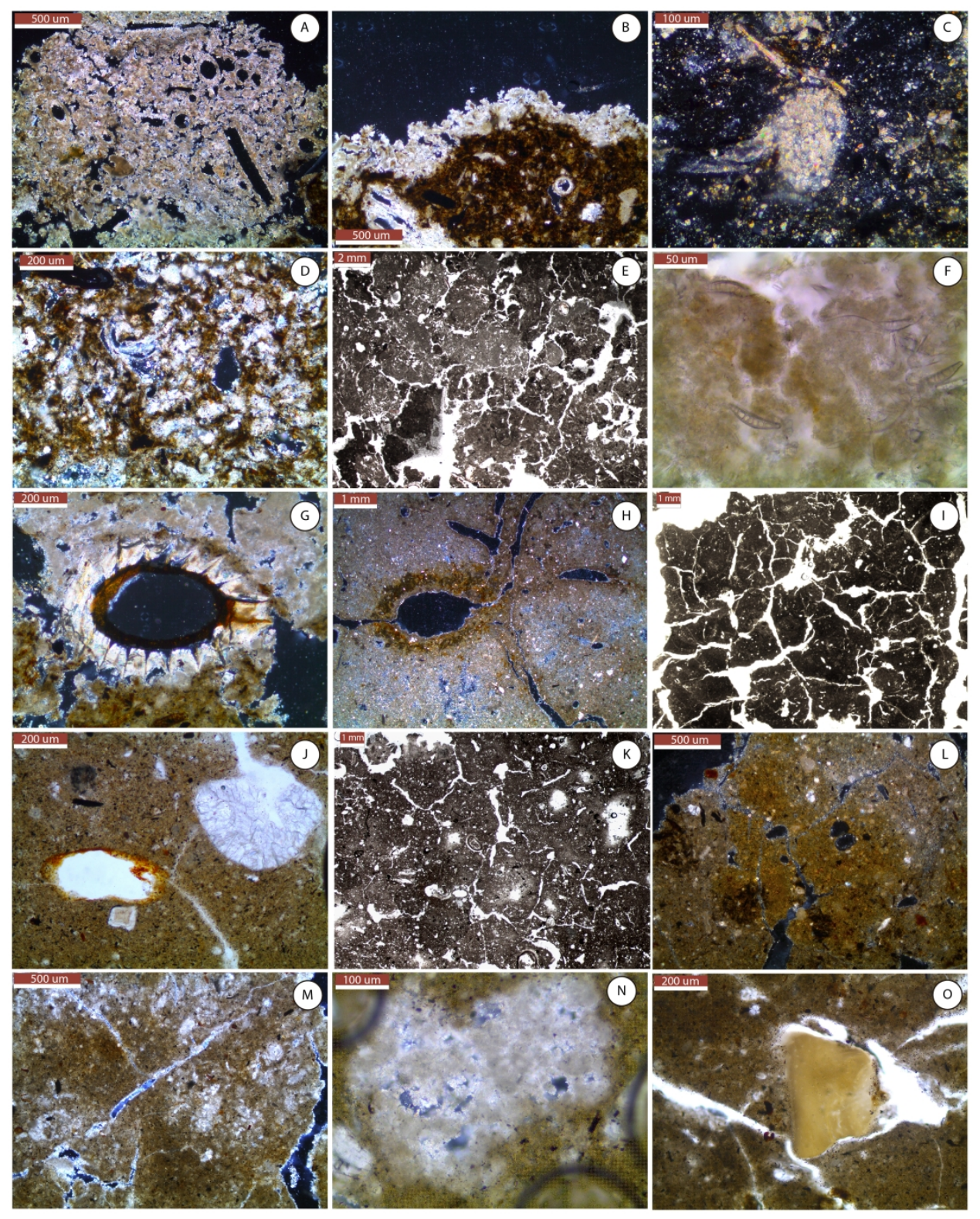

Figure 5. Selected micromorphological features from upper NAR2 (Micromorphological Units MIII to MI, see text and Fig.6). A) Orthic tuffaceous concretion, from aggregation of smaller micritic elements and pseudomorphs (MI, N204, XPL-Crossed Polarized Light). B) Tuffaceous calcite capping. Note dark micromass, rich in organic matter (MI, N204, XPL). C) Orthic calcite nodule in a dark cristallitic to isotropic micromass (MI, N204, XPL). D) Micromass rich in calcitic grains strongly bioturbated and reorganized by biological activity (MI, N204, XPL). E) Complex microstructure, subangular with granular substructure or crumbly subangular (MI, N204, transmitted light). F) Diatoms embedded in carbonate-rich micromass (MI, N204, PPL-Plane Polarized Light). G) Characeae oogon. Note the two different types of micromass: brown, clayey, rich in organic fragments and microcharcoal (base) vs. massive micritic-microsparitic micromass (top) (MI, N204, XPL). H) Iron and micritic hypocoatings around a chamber and fissural to canalicular voids (MIII, N208, XPL). I) Subangular blocky microstructure of an organo-mineral unit (MIII, N207, transmitted light). J) Iron hypocoating and biospheroid, note silty clay micromass rich in microcharcoal and small organic fragments (MII, N205, PPL). K) Granular microstructure of a organo-mineral unit, note partial collapse of porosity due to secondary clogging (MIII, N210, transmitted light). L) Silty clay matrix highly impregnated 
by oxidized iron, and injection of matrix aggregates (rich in organic matter) from upper layers (MII, N205, $\mathrm{XPL}$ ). M) Concentration of micritic to microsparitic calcite in the matrix (and in voids), some evolving to nodules (MIII, N208, XPL). N) Calcite nodule (micritic to microsparitic) in development by impregnation of the matrix (MIII, N209, XPL). O) Small bone fragment embedded in a silty clay matrix with microcharcoal and organic microdebris (MII, N205, PPL).

$286 \times 358 \mathrm{~mm}(300 \times 300 \mathrm{DPI})$ 


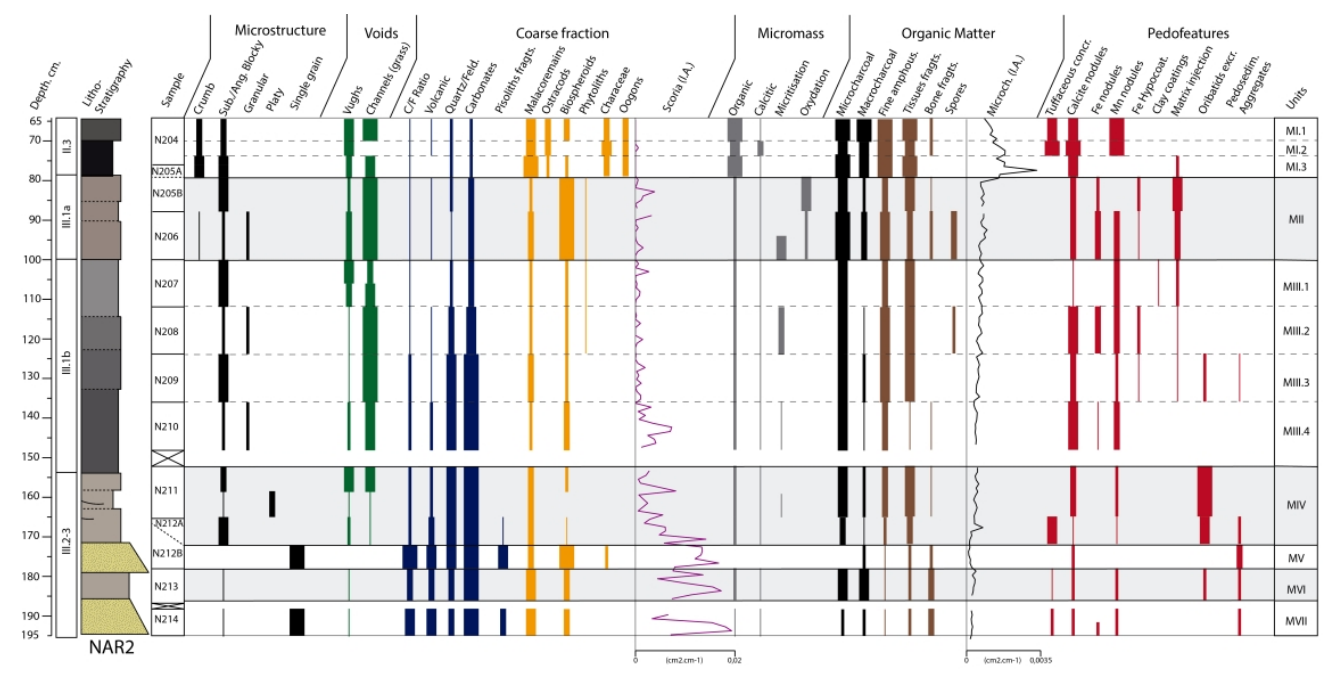

Figure 6. Summary diagram of main micromorphological features of NAR2 between 65 and $195 \mathrm{~cm}$. Bars width indicates their relative abundance (rare, few, several /some, abundant, very abundant, see Table 3 in Supplementary Information), or alternatively their development degree. Scoria and microcharcoal are quantified using image analysis (IA). C/F: Coarse/Fine ratio, here $20 \mu \mathrm{m}$.

$462 \times 232 \mathrm{~mm}(300 \times 300 \mathrm{DPI})$ 

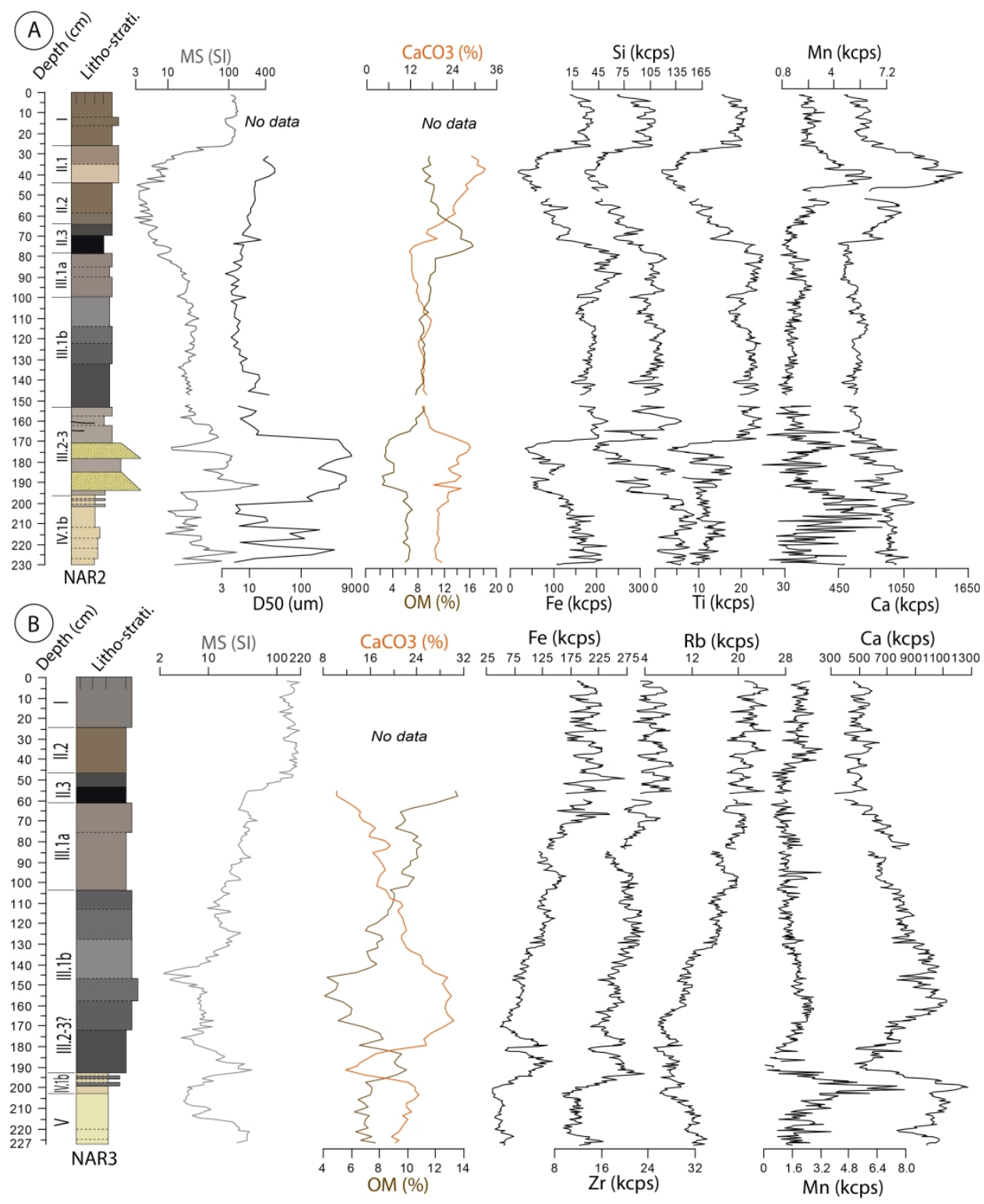

Figure 7. A) Selected elements and sedimentological data for NAR2. Values are in 10-5 SI (Magnetic Susceptibility-MS-) and in counts per second (CPS) for the XRF. B) Selected elements and sedimentological data for NAR3.

$323 \times 404 \mathrm{~mm}(300 \times 300 \mathrm{DPI})$ 


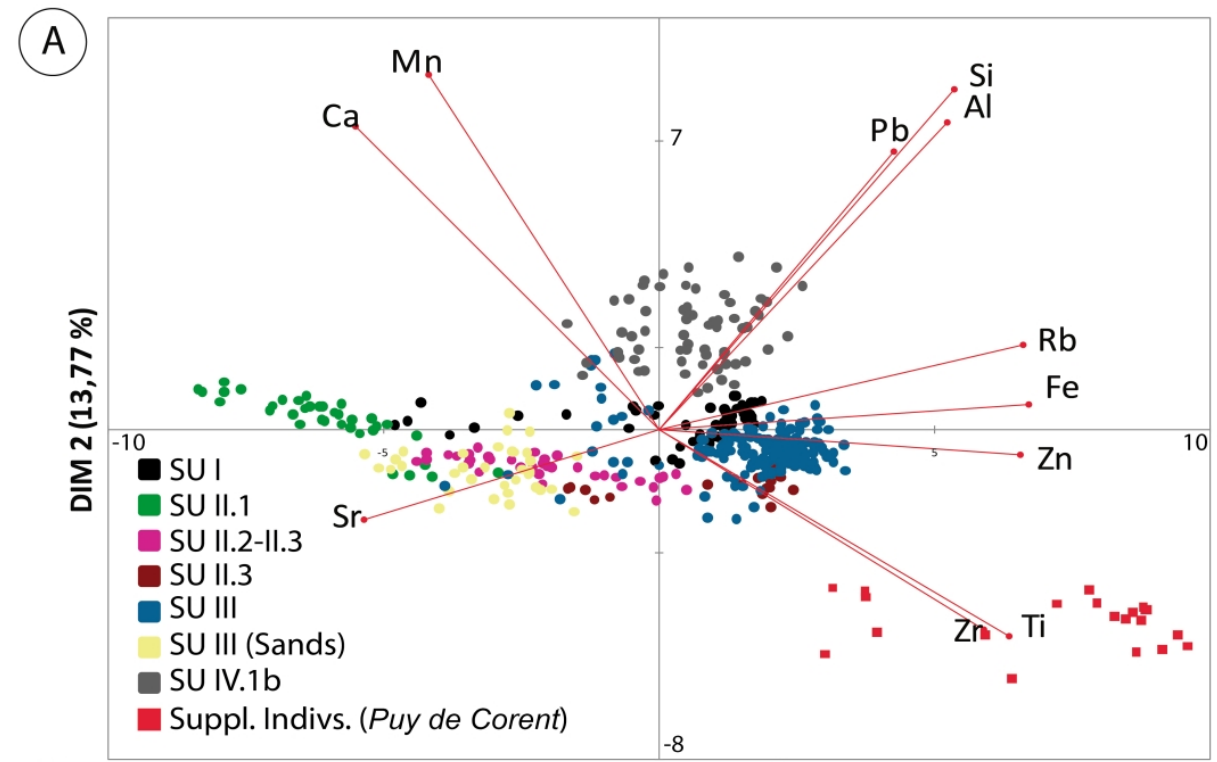

(B)

$\operatorname{DIM} 1(64,86 \%)$

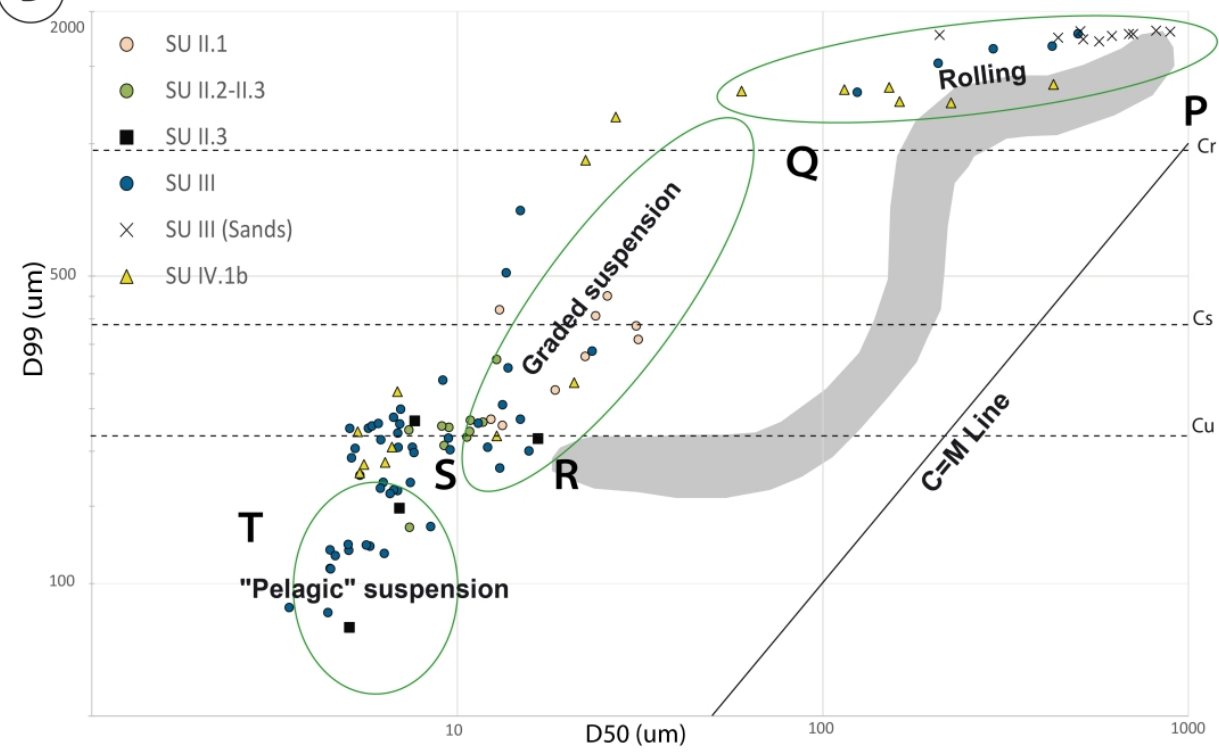

Figure 8. A) PCA biplot of selected geochemical variables according to dimensions 1 and 2, individuals are distributed by Sedimentary Unit. Note supplementary individuals (red squares, data from Mayoral et al., 2018). B) Passega or C-M diagram of NAR2 with grain-size data by Sedimentary Unit. Grey area represents reference C-M diagram by Passega (1977).

$323 \times 404 \mathrm{~mm}(300 \times 300$ DPI $)$ 

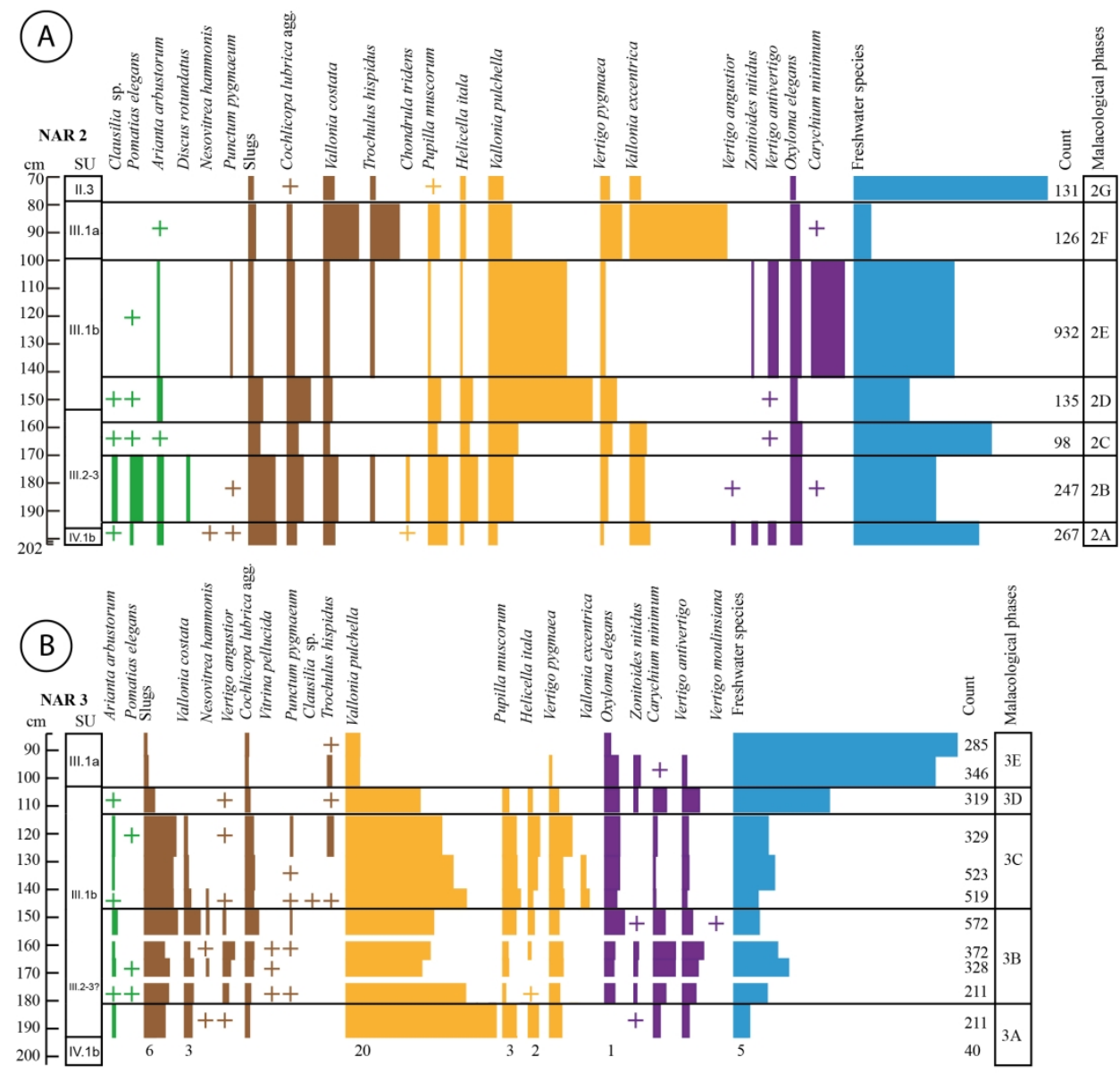

Shade-demanding species
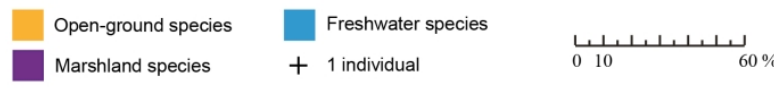

Figure 9. Diagrams of specific composition of molluscan assemblages A) NAR2 B) NAR3. Contiguous $2 \mathrm{~cm}-$ thick sediment samples were grouped in bigger sets when necessary in order to reach a significant number of shells. Species are classified by ecological affinities and by order of occurrence.

$210 \times 216 \mathrm{~mm}(300 \times 300 \mathrm{DPI})$ 

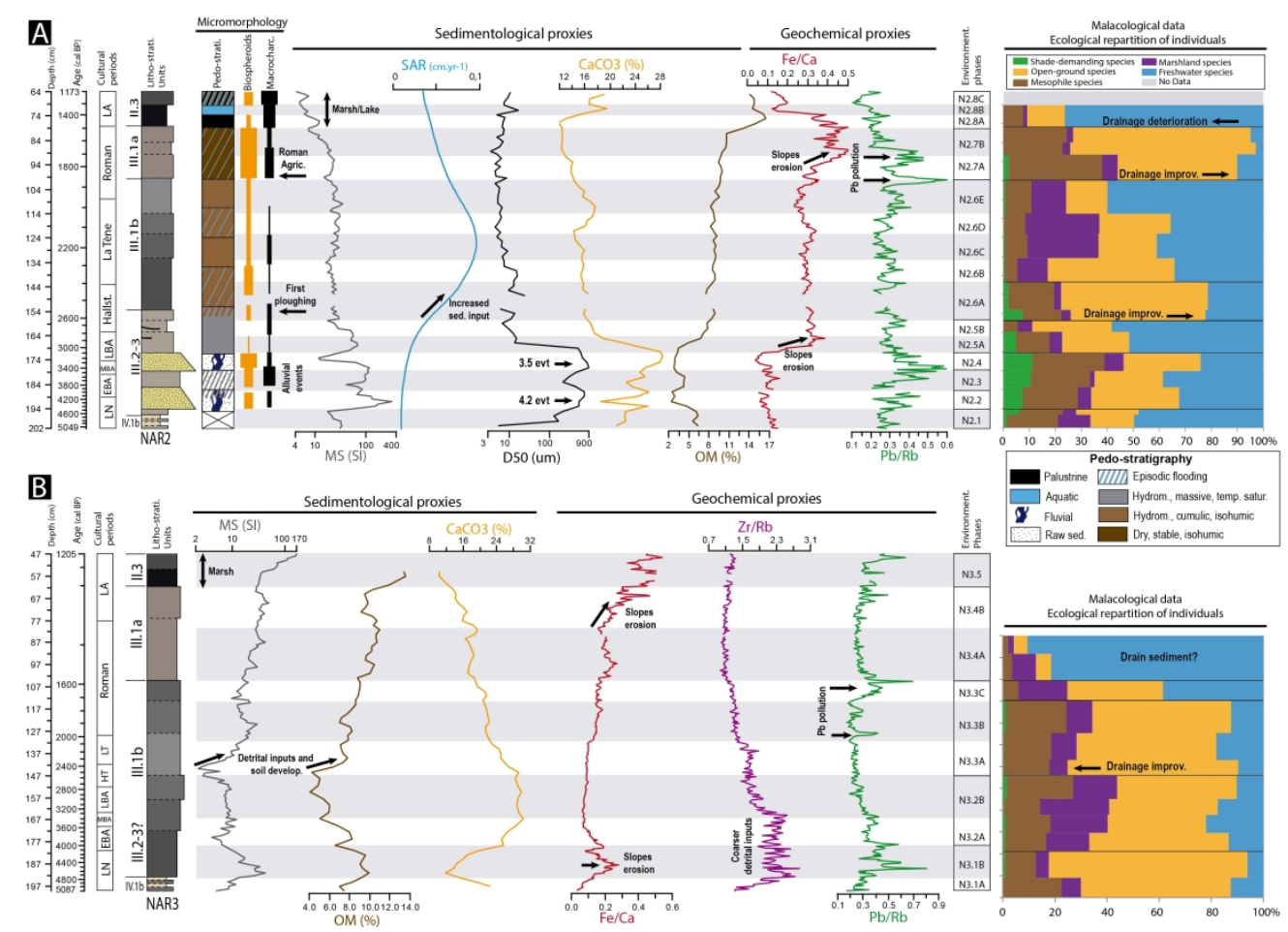

Palustrine WIIIIA Epsisodic flooding

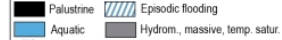
I. Aquatic
Fiwial
Rew sed.

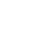

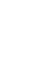

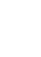

(2)

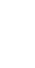

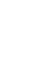

(n)

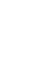

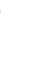
(1)

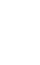

(n)

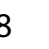

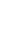
(a)

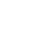

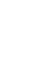

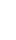

Figure 10. Multi-proxy synthetic diagram for NAR2 (A) and NAR3 (B) cores (MS: Magnetic Susceptibility. D50: median grain-size. SAR: Sediment Accumulation Rate. OM: Organic Matter content).

$$
297 \times 215 \mathrm{~mm}(300 \times 300 \text { DPI })
$$




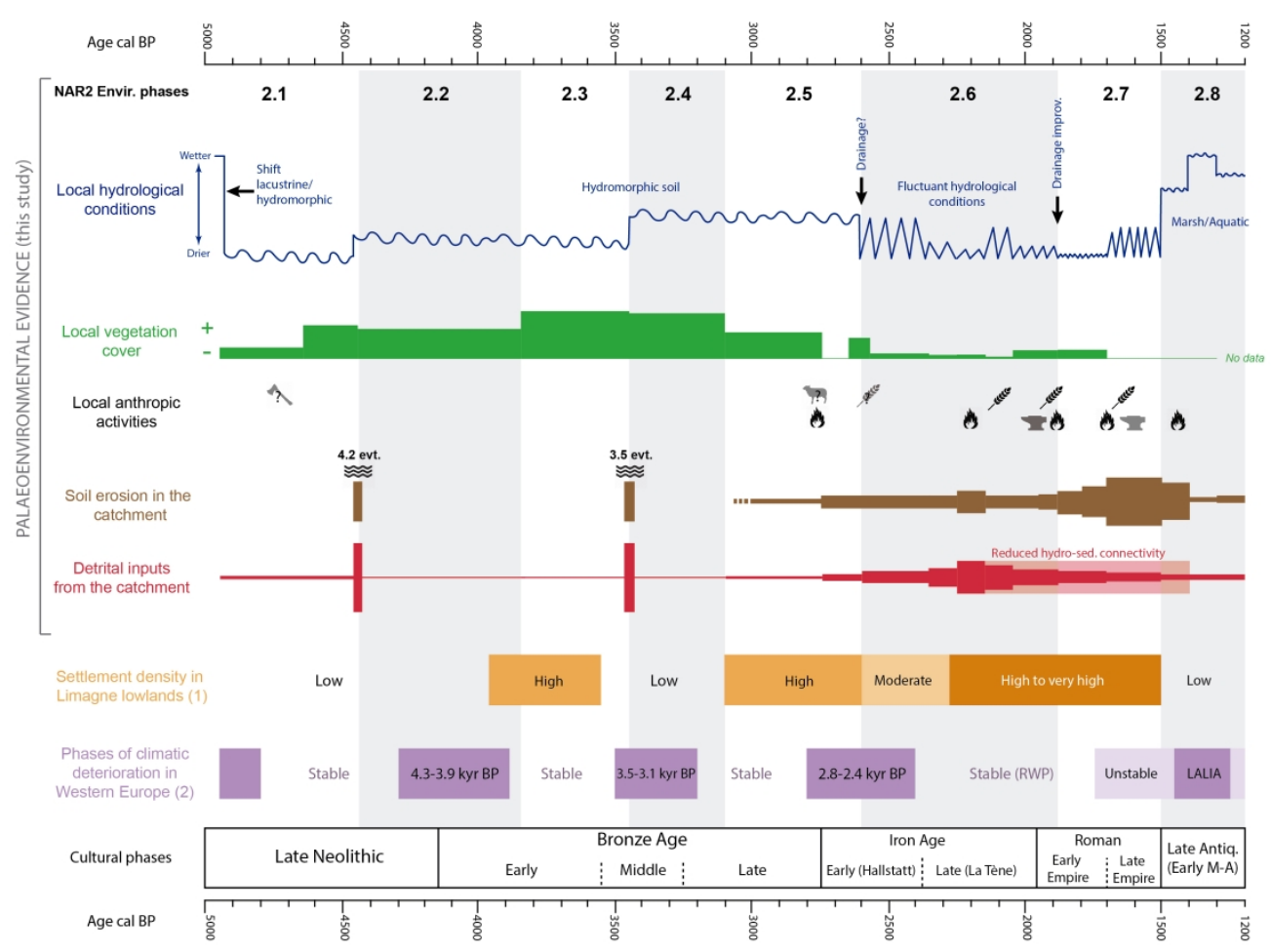

Figure 11. Comparison of palaeoenvironmental evidence in la Narse de la Sauvetat between 5000 and 1200 cal BP (derived from core NAR2, this study) with regional archaeological data in Limagne plain and climatic changes in Western Europe. NAR2 environmental phases are from Fig. 10A. Representations of local hydrological conditions, soil erosion in the catchment and detrital inputs are qualitative (relative level or thickness according to process intensity) and based on data from Fig. 10. High-energy hydro-sedimentary episodes related to 4.2 and $3.5 \mathrm{kyr}$. cal BP climatic events are indicated (note a chronological offset of 150$200 \mathrm{yr}$. of the first episode, see the text for details). Local vegetation cover (qualitative) is represented by the proportion of shade-demanding malacological species vs. other terrestrial malacological species. Anthropic activities (landscape opening, use of fire, pastoral activity, agriculture and metallurgical activity) are represented by symbols. RWP: Roman Warm Period. LALIA: Late Antiquity Little Ice Age. Settlement density in Limagne is based on (1) Ballut and Argant, 2004; Couderc, 2019; Daugas and Raynal, 1989; Milcent and Mennessier-Jouannet, 2007; Raynal et al., 2003; Trément et al., 2007; Trément, 2011. Phases of climatic deterioration in Western Europe are based on (2) Berger et al., 2007; Brisset et al., 2013; Buntgen et al., 2011; Carozza et al., 2015; Fletcher, Debret and Goñi, 2013; Holzhauser et al., 2005; Joerin et al., 2006; Magny, 2004; Magny et al., 2009; McCormick et al., 2012; Van Geel and Magny, 2002; Walker et al., 2019; Walsh et al., 2019.

$282 \times 207 \mathrm{~mm}(300 \times 300$ DPI $)$ 

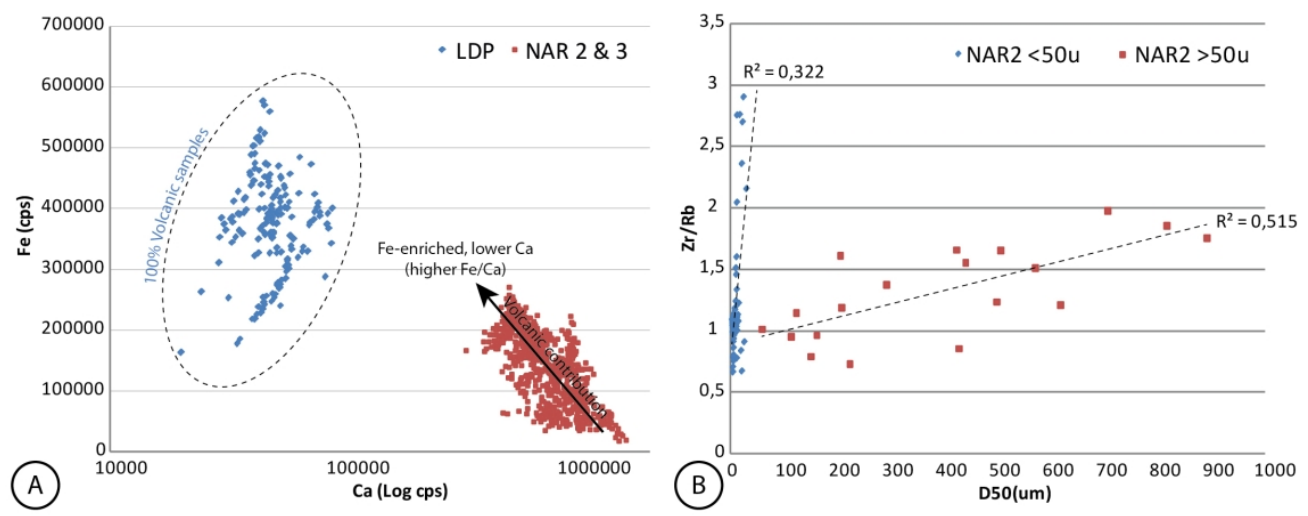

Figure 12. A) Scatterplot showing relative contents in Fe and Ca (measured by XRF core-scanner in cps, Log scale for Ca) of $100 \%$ volcanic samples (LDP blue dots, core from the summit of the Puy de Corent, lithology: basalts and scoria, data from Mayoral, 2018), vs. samples from NAR2 \& NAR3 in the calcareous lowlands (this study, red dots). $100 \%$ volcanic samples have clearly higher Fe/Ca ratio. Note also the gradient in the Fe/Ca ratio for NAR2 \& NAR3 samples interpreted as increased volcanic sediment content. B) Scatterplot showing relationship between $\mathrm{Zr} / \mathrm{Rb}$ ratio and D50 in NAR2 samples, for two different grain-size classes. $\mathrm{Zr} / \mathrm{Rb}$ is very sensitive to grain-size increase in clays and fine to coarse silts ( $<50$ um, blue dots), and moderately sensitive for very coarse silts and sands (>50um, red dots). Note that relatively low R2 is mainly due to the reduced number of samples.

$185 \times 73 \mathrm{~mm}(300 \times 300$ DPI $)$ 